This is a non-peer reviewed pre-print.

The Manuscript is currently under review in Marine and Petroleum Geology. Please note the subsequent version of this manuscript may have a different content.

\title{
Multiple episodes of sand injection leading to accumulation and leakage of hydrocarbons along the San Andreas/San Gregorio fault system, California.
}

\author{
Giuseppe Palladino ${ }^{1,2^{*}}$, Roberto Emanuele Rizzo ${ }^{1}$, Gustavo Zvirtes ${ }^{1}$, Antonio Grippa ${ }^{1}$, \\ Andrew Hurst ${ }^{1}$, Ruy Paulo Philipp ${ }^{4}$, David Healy ${ }^{1}$ and G. Ian Alsop ${ }^{1}$ \\ ${ }^{1}$ Department of Geology and Petroleum Geology, School of Geosciences, University of Aberdeen, Aberdeen, \\ UK \\ ${ }^{2}$ Dipartimento di Scienze, Università degli Studi della Basilicata, Potenza, Italy \\ ${ }^{4}$ Departamento de Mineralogia e Petrologia, Universidade Federal do Rio Grande do Sul, Porto Alegre, Rio \\ Grande do Sul, Brazil \\ *Corrisponding author: Giuseppe Palladino, E-mail: Giuseppe.palladino@abdn. ac.uk
}

\section{Abstract}

The presence of sand injections has proven to enhance the likelihood of hydrocarbon traps within siliciclastic successions. Through the development of large interconnected networks of sills and dykes, sand injection complexes provide a volume of porous and permeable rocks within the low permeability host units. Overall, the formation of sand injection complexes requires extensive fracturing and hydrofracturing, which can be particularly pronounced when sand injections are coupled with brittle tectonic deformation. In exceptional circumstances, this process may threaten the integrity of the reservoir top seal thereby preventing further hydrocarbon accumulation. Studying exceptional exposures along the coastal area of Santa Cruz in California, we report evidence for top seal failure associated with injection episodes. Two distinct sand injection episodes are proposed. A first event, datable to Late Miocene, allowed for large volumes of sand to be emplaced within the top-seal units followed by accumulation of hydrocarbons within newly injected sandstones. Later, a series of brittle tectonic events, associated with San Andreas/San Gregorio Fault System, caused 
This is a non-peer reviewed pre-print.

The Manuscript is currently under review in Marine and Petroleum Geology. Please note the subsequent version of this manuscript may have a different content.

remobilisation and accumulation of sand along newly formed fault planes. This combination of pervasive brittle deformation and sandstone injection along fault structures, as this detailed case study documents, can disrupt the integrity of a host unit, leading to the overall failure of a top seal and leakage of hydrocarbons.

Keywords: Sandstone intrusions; Santa Cruz Injection Complex; Santa Cruz petroleum system; Sandstone-filled faults; Hydrocarbon leakage; San Andreas/San Gregorio fault system; California.

\section{Introduction}

Fracturing and faulting processes associated with emplacement of sandstone intrusions in the shallow crust are caused either by an excess of pore-fluid pressure, or regional tectonic stresses, and are among the main mechanisms responsible for top seal failure in sedimentary successions where sands alternate with low-permeability mudstones (Hurst et al., 2011). In particular, hydrofracturing and faulting processes related to fluid overpressure commonly initiate at the interface between the reservoir rocks and top seal strata, when fluid pressure exceeds the fracture gradient and then propagates throughout the top seal sequence (Jolly and Lonergan, 2002). Fractures and faults related to regional tectonic stresses commonly involve the entire reservoir/top seal system and, also, cut through the interface separating the two different portions (Palladino et al., 2018).

In general, brittle deformation processes associated with emplacement of sandstone intrusions can lead to either the partial or the complete breaching of the sealing sequence, with two contrasting outcomes for oil retention: i) partial top seal breaching generally will result in enhanced reservoir capacity, as fault and fracture apertures, together with highly-permeable sandstone intrusions, provide new capacity for hydrocarbon accumulation; ii) alternatively, 
This is a non-peer reviewed pre-print.

The Manuscript is currently under review in Marine and Petroleum Geology. Please note the subsequent version of this manuscript may have a different content.

complete breaching of the sealing sequence will prevent hydrocarbons accumulation due to bypass mechanisms or, in the case that hydrocarbons are already accumulated in the reservoir, lead to leakage phenomena (Cartwright et al., 2007).

Given the potential importance of the above relationships, the study of the interactions between faults, fractures and sandstone intrusions cannot be ignored when exploring for hydrocarbon reservoirs. In this work, we present direct field evidence for top seal failure associated with emplacement of sandstone intrusions forming the Santa Cruz Injection Complex (SCIC) in the coastal area of California (Thompson et al., 2007) (Fig. 1). The SCIC shares its main elements with other sand injection complexes in California (e.g. Vigorito and Hurst, 2010; Scott et al., 2013) displaying a complete suite of components which comprise a source rock, an intrusive network, and an extrudite complex (Scott et al., 2009). The SCIC is part of the Santa Cruz petroleum system, thereby representing an ideal analogue for hydrocarbon-bearing sand injections in the subsurface (Dixon et al., 1995; Duranti et al., 2002; Duranti and Hurst, 2004). The first studies describing sand injections in the Santa Cruz area, date back to the beginning of the $20^{\text {th }}$ century (Eldridge, 1901; Newsom, 1903) and focused on the potential of mining these tar-sand deposits. After tar production decreased, successive studies focussed on the mechanisms leading to the emplacement of sandstone intrusions, and on the relationships between sand injections and tectonic structures in the area (Phillips, 1990; Molyneux, 1999; Boehm and Moore, 2002; Jolly and Lonergan, 2002; Thompson et al., 2007; Scott et al., 2009; Sherry et al., 2012). Based on contradictory field evidence, which indicates the contemporaneous occurrence of sandstone intrusions emplaced along faults, and sandstone intrusions overprinted by tectonic structures, two main mechanisms invoking episodes of pore-fluid overpressure, and tectonic processes were formulated. It is important to note that in both cases, the resulting models considered that the SCIC was emplaced as a single event. 
This is a non-peer reviewed pre-print.

The Manuscript is currently under review in Marine and Petroleum Geology. Please note the subsequent version of this manuscript may have a different content.

In this study we have undertaken a detailed geological survey along the coastal sector between Santa Cruz and Davenport (Fig. 1) and have focussed on the cross-cutting relationships between sandstone intrusions and tectonic structures in the SCIC. This outcropbased investigation allowed us to recognise that the present architecture of the SCIC is a consequence of a two-stage injection. During the first stage, which occurred in the Late Miocene, the partial failure of the top seal leads to the emplacement of sandstone intrusions within the Santa Cruz Mudstone. The high resealing capacity of the system at this time allowed successive hydrocarbon accumulation. During the second stage, sandstones intruded along high angle extensional faults associated with the San Andreas/San Gregorio fault system. The age of this later event is not well-constrained, although must have occurred between the Late Miocene and the Quaternary and caused the leaking of hydrocarbons previously accumulated in the system. The main aims of this work are: i) to present evidence for two different sandstone injection stages leading to the building of the SCIC; ii) to discuss the relationships between tectonic structures and sandstone intrusions, and provide clear field descriptions about the cross-cutting relationships occurring between the two recognised events; iii) to propose an evolutionary model showing the initiation, development and the successive failure of the of Santa Cruz petroleum system.

\section{Geological setting}

\subsection{Geology of the Santa Cruz coastal area}

The coastal sector between the City of Santa Cruz and Davenport is part of the "Ben Lomond domain" (sensu Aydin and Page, 1984), which is a relatively undeformed area between the two major San Andreas and San Gregorio dextral strike-slip fault zones (Dickinson et al., 2005) (Fig. 1a-c). The outcrops consist of a Middle Miocene-Pliocene 
This is a non-peer reviewed pre-print.

The Manuscript is currently under review in Marine and Petroleum Geology. Please note the subsequent version of this manuscript may have a different content.

sedimentary succession unconformably overlying the granitic/metamorphic Salinian basement, which forms the southwest flank of the Ben Lomond Mountain (Clark, 1981; Page et al., 1998) (Fig. 1d). The base of the sedimentary succession consists of shallow-marine arkosic sandstone of the Middle Miocene Lompico Formation, which rests uncomformably upon the crystalline basement. This formation reaches a maximum thickness of about $240 \mathrm{~m}$ and is conformably overlain by bathyal biosiliceous mudrocks and sandstones of the Monterey Formation (Clark, 1981). The Monterey Formation reaches a thickness of $800 \mathrm{~m}$ in the study area and is unconformably overlain by the Santa Margarita Sandstone (Fig. 1d). This formation consists of coarse-grained, large-scale cross-bedded arkosic sandstones and finegrained bioturbated sandstones, deposited in a tidal/nearshore depositional environment. The unit has a maximum thickness of $130 \mathrm{~m}$ and the coarse-grained facies contain accumulations of oil and tar. The Santa Margarita Sandstone is considered to be the reservoir of the Santa Cruz petroleum system, whereas the Monterey Formation represents the source rock (see the next section). The Santa Cruz Mudstone stratigraphically overlies the Santa Margarita Sandstone (Fig. 1d), and consists of organic-rich, thickly bedded, biosiliceous mudstone and thin porcelanite layers containing dolomite and calcite concretions. Green mudstone horizons up to $10 \mathrm{~cm}$ thick locally alternate with the previously described mudstone lithologies. The Santa Cruz Mudstone was deposited in a shelf environment approximately 9.0-7.0 Ma ago (Barron, 1986) and reaches a maximum thickness of $2700 \mathrm{~m}$. It is considered to be the top seal for the Santa Cruz petroleum system. The Purisima Formation is the youngest unit recognised in the Santa Cruz area. It consists of Miocene to Pliocene, very thick-bedded tuffaceous and diatomaceous siltstones alternating with thick-bedded andesitic sandstones, deposited in a neritic environment which in places reaches $300 \mathrm{~m}$ in thickness.

The Santa Cruz succession forms the southwestern flank of the of the Ben Lomond mountain fold (Stanley and McCaffrey, 1983) which is a southeast-plunging anticline formed 
This is a non-peer reviewed pre-print.

The Manuscript is currently under review in Marine and Petroleum Geology. Please note the subsequent version of this manuscript may have a different content.

\subsection{The Santa Cruz petroleum system} Clark, 1981, Brabb, 1989) (Fig. 1b).

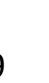

between the San Andreas and San Gregorio fault zones (Fig. 1b). Other important tectonic structures in the area are the Ben Lomond and Zayante fault zones (Clark and Rietman, 1973,

Displacement across the Pacific-North America transform margin has been slightly compressive since $8 \mathrm{Ma}$ (Atwater and Stock, 1998), resulting in a progressive tectonic uplift of the area marked by folding and faulting. In particular, a series of NW-SE trending anticlines and synclines formed between the Zayante/Ben Lomond fault system and the San Andreas Fault whereas, west of the Ben Lomond fault, a gently SW-dipping homocline forms the major structure in the study area. Uplift in the Santa Cruz area has been continuous between the late Tertiary and Quaternary, with a calculated uplift rate of $0.16 \mathrm{~m} / 1,000 \mathrm{yr}$ (Bradley and Griggs, 1976). More recently Bürgmann et al. (1994) suggested an average uplift rate of the order of $0.8 \mathrm{~mm} / \mathrm{yr}$ over the last $4.6 \mathrm{~m} . \mathrm{y}$. The SCIC is currently exposed along wavecut platforms and cliffs in the Santa Cruz Mudstone, located on the southwestern side of Ben Lomond Mountain. complete sequence of source rock, reservoir, top seal, and overburden represented by the Monterey, Santa Margarita Sandstone, Santa Cruz Mudstone and Purisima formations, respectively (Phillips, 1990; Hosford Scheirer et al., 2013) (Fig. 1d). Petroleum generation occurred during a narrow span of time between 7Ma and 5Ma (Hosford Scheirer et al., 2013). Although the Monterey Formation is considered to be the source rock for the SCPS, geochemical studies suggest that the Santa Cruz Mudstone is another possible petroleum source (Lillis and Stanley, 1999). SCPS mainly consists of tar-saturated sandstones, with oil and gas recognised in the Santa Cruz Mountain area and also along the coast. Hydrocarbons represented by both oil and gas are also present offshore along the Santa Cruz continental 
This is a non-peer reviewed pre-print.

The Manuscript is currently under review in Marine and Petroleum Geology. Please note the subsequent version of this manuscript may have a different content. margin (Mullins and Nagel, 1982; Heck et al., 1990). In the coastal area, the reservoir rocks mainly consist of heavy oil and tar-saturated sandstones irregularly distributed in an area of about $120 \mathrm{~km}^{2}$ included between Davenport, Bonny Doon and Santa Cruz (Fig. 1). Tarsaturated sandstones and hydrocarbon seeps occurring in the Santa Cruz coastal area are wellknown since the end of the 19th century (Eldridge, 1901; Newsom, 1903; Jenkins, 1930), and attained moderate economic significance following the 1906 earthquake in San Francisco when sand from the Santa Margarita Sandstone was mined to provide asphalt for road rebuilding. In the same area, the occurrence of petroleum has also been ascertained and estimates of oil reserves varied from 10 million bbl to 20 million bbl which classifies the SCPS as a minor oil field (Page and Holmes, 1945; Phizackerley and Scott, 1978; Hallmark, 1980). Although the Santa Cruz petroleum system has only limited economic relevance, the significance of its study lies in the fact that it represents a valid analogue for larger subsurface oil fields.

\section{The Santa Cruz Injection Complex}

\subsection{Factors controlling emplacement, geometry and architectural organization of sandstone} intrusions

Sandstone intrusions originate by the forceful emplacement of fluidised sand into an actively propagating hydraulic fracture system within low permeability host rocks. Pore-fluid pressure must exceed the fracture toughness of the host strata. Additionally, to mobilise sand from unconsolidated parent depositional units the velocity of the pore-fluid must exceed the minimum fluidisation velocity (Lowe, 1975). For fine- to medium grained sand the minimum fluidisation velocity is estimated to range between $0.001 \mathrm{~ms}^{-1}$ and $0.01 \mathrm{~ms}^{-1}$, although during large-scale injection much higher velocity is inferred (Duranti and Hurst, 2004; Hurst et al., 
This is a non-peer reviewed pre-print.

The Manuscript is currently under review in Marine and Petroleum Geology. Please note the subsequent version of this manuscript may have a different content.

2011). Pore-fluid is generally driven upward following the pressure gradients that form between high-pressured zones in the shallow crust, typically at depths of less than $1.5 \mathrm{~km}$ burial and the Earth's surface (Vigorito and Hurst, 2010; Hurst et al., 2011).

Variations in pore-fluid pressure within the host strata and the underlying pressure cell typically form sandstone intrusion complexes that consist of four main architectural elements comprising the parent units, dikes, sills and extrudites (Vigorito and Hurst, 2010) (Fig. 2a). The distribution and geometry of sandstone intrusions in the crust are generally the result of the interaction between pore-fluid pressure and the lithostatic pressure (overburden). For example, sills mainly develop at a depth where the fluid pressure is equal or greater than the lithostatic pressure (lithostatic equilibrium surface, LES of Vigorito and Hurst, 2010) forming a sill zone in which the greatest volume of injected sand occurs (Fig. 2a). Dikes dominate immediately above the parent units (the lower dike zone) and between the sill zone and the sand extrudites (upper dike zone) (Fig. 2a). Unlike other sandstone intrusion complexes occurring in central California (i.e. the Panoche Giant Injection Complex of Vigorito and Hurst, 2010) the SCIC does not show a vertical and lateral continuity due to tectonic disturbance. However, the different architectural elements are still recognisable in different outcrops exposed along the Santa Cruz coastal area.

The distribution and geometry of sandstone intrusions also depends on whether dominant regional tectonic stress fields are developed. Based on natural examples, and laboratory experiments which modelled unconsolidated homogeneous material as the host unit, it has been demonstrated that intrusions tend to fill pre-existing tectonic structures, and that they predominantly form low to high angle dikes in tectonically active areas (Galland et al., 2003; 2007; Ferre' et al., 2012; Palladino et al., 2016; 2018) (Fig. 2b). Flat-lying intrusive geometries are still possible in compressional settings when the maximum principal stress $\left(\sigma_{1}\right)$ is horizontal and the minimum principal stress $\left(\sigma_{3}\right)$ is vertical. 
This is a non-peer reviewed pre-print.

The Manuscript is currently under review in Marine and Petroleum Geology. Please note the subsequent version of this manuscript may have a different content.

The SCIC extends for $15 \mathrm{~km}$ between the city of Santa Cruz and Davenport and for several $\mathrm{km}$ inland (Fig. 1). It consists of three different architectural elements termed the parent units, the intrusive network, and extrudites that will be described in the following sections. We also include sandstone intrusions within the SCIC that are emplaced along faults and are not temporally correlated with the majority of sandstone intrusions recognised in the study area.

\subsection{Parent units}

Although the parent-intrusion relationships are typically not well exposed, the Santa Margarita Sandstone is generally interpreted to be a parent unit (Boehm and Moore, 2002; Thompson et al. 2007). Multiple parent sandstone units were invoked by Clark (1981) for the SCIC using mineralogical data from exposures at Panther Beach/Yellowbank Creek localities (Fig. 1). The Pliocene Purisma Formation was identified as a parent unit based on similar overall composition and the occurrence of andesine feldspar, which has a volcanic provenance and is unknown in the Santa Margarita Sandstone (Scott et al., 2009). For the Purisima Formation (Early Pliocene; Norris, 1986) to form a parent unit would require its juxtaposition below the Miocene Santa Cruz Mudstone at the time of sand injection. This would have occurred not earlier than the earliest Pliocene and implies that the large intrusions at Panther Beach/Yellowbank Creek were not emplaced until then. Unfortunately, the poor lateral exposure of the SCIC combined with sparse biostratigraphic control and, very limited mineralogical data from the Santa Margarita Sandstone, compromise interpretation.

\subsection{The intrusive sand network}


This is a non-peer reviewed pre-print.

The Manuscript is currently under review in Marine and Petroleum Geology. Please note the subsequent version of this manuscript may have a different content.

The SCIC has a widespread and well-developed intrusive network, which mainly consists of dikes and occasional sills. Saucer-shaped intrusions are also locally present. Single intrusions generally range from a few centimetres to a decimetre thick, while isolated dikes or sills can locally be several metres thick. Although the distance from one large intrusion to another can be significant (in the order of tens or hundreds of metres), the presence of minor intrusions provides good connectivity throughout the injection network. Connectivity between sandstone intrusions is demonstrated by the common occurrence of tar that has migrated along the fractures cropping out in study area.

\subsubsection{Dikes}

Dikes are very well exposed in the study area, with key localities at 4 Mile Beach and Bonny Doon (Fig. 1). Within the general Santa Cruz coastal area, dikes are sub-vertical, or at high angles to bedding, and occur as single intrusions or swarms that are water and tar saturated (Fig. 3a-e). Single dikes vary in aperture from a few centimetres to more than $1 \mathrm{~m}$. Bifurcation (Fig. 3a), side-stepping and marked changes in orientation are common (Fig. 3b, c). Dikes are typically planar with sharp discordant margins with host strata, although undulating, irregular contacts also occur, usually in association with intensely fractured zones. Mudstone clasts of host strata commonly form "floating" textures in a sandstone dike matrix. These clasts are generally angular to slightly rounded and jigsaw textures occur (Duranti and Hurst, 2004) (Fig. 3d-e). The internal structure of the sandstone intrusions is characterised by mm- to cm-spaced banding. Dikes fall into three main trends that are oriented N-S, WSWENE and SW-NE (Fig. 3f). 
This is a non-peer reviewed pre-print.

The Manuscript is currently under review in Marine and Petroleum Geology. Please note the subsequent version of this manuscript may have a different content.

Sills mainly crop-out at Panther Beach/Yellowbank Creek, while small-scale sills also occur at 4 Mile Beach (Fig. 1). Sills typically display low-angle $\left(<5^{\circ}\right)$ discordance with bedding (Fig. 4), and range in thickness from a few centimetres to several decimetres, with the exception of the Panther Beach/Yellowbank Creek locality where sills are up to $\sim 20 \mathrm{~m}$ in thickness (Thompson et al., 2007; Scott et al., 2009) (Fig. 1). Sill margins are irregular with lateral thickness variation and abrupt lateral terminations. The lower contacts of sills are often erosive with scoured surfaces common, while upper boundaries are commonly discordant with the host strata (Fig. 4a, b). These sharply discordant erosive contacts with overlying host strata conclusively demonstrate the intrusive origin of the sills. Meter to 10's of meters wide convexup features, termed scallops (Hurst et al., 2005), are sometimes associated with dikes that emanate from them into the overburden. Mudstone breccias with jigsaw configuration of clasts, together with isolated mudstone rafts, occur along the upper and lower margins of sills. Internal sedimentary structures are dominated by mm- to dm-thick banding, which is oriented approximately parallel to the margins of the sandstone intrusions. Plane-parallel and crosslamination are also commonly observed. Within the thickest sills, sedimentary features including convolute lamination, fluid-escape structures and pipes suggest turbulent flow during emplacement (Scott et al., 2009).

\subsubsection{Saucer-shaped intrusions}

Saucer-shaped, tar-saturated sandstone intrusions are very well exposed at 4 Mile Beach (Fig. 1). In cross-section, they consist of an inner bedding-parallel sandstone intrusion that are connected laterally with two outer sills by means of segments inclined at between $15^{\circ}$ and $60^{\circ}$. Similar features observed on seismic images are often referred to as wings (Huuse et al., 2007, Jackson et al., 2011). Inner sills, that are typical of large saucer-shaped intrusions, are not observed (Huuse et al., 2007; Hurst and Vigorito, 2017). The saucer-shaped sandstone 
This is a non-peer reviewed pre-print.

The Manuscript is currently under review in Marine and Petroleum Geology. Please note the subsequent version of this manuscript may have a different content.

intrusions coalesce to form a composite intrusion with "petals of a flower" geometry, which are connected by smaller, contemporaneous dikes. Bifurcation and convergence of the saucers is characteristic (Fig. 4c, d). A nested geometry of saucers occurs where smaller intrusions overlie large saucers and are linked by dikes with cuspate geometry (Fig. 4e, f). Saucer-shaped intrusions are 2 to $15 \mathrm{~cm}$ thick with undulating, stepped margins. Although sandstone intrusions probably comprise less than $10 \%$ of the rock volume they provide excellent connectivity as demonstrated by the pervasive tar saturation.

\subsubsection{Sandstone-filled faults}

Sandstone intrusions emplaced directly along tectonic structures are a volumetrically small, and therefore frequently overlooked, characteristic of sandstone intrusion complexes (Palladino et al., 2016, 2018). In the SCIC, they are an integral part of the injection complex and predominantly consist of sandstone-filled normal faults (SFNF sensu Palladino et al., 2018) with sandstone intrusions along strike-slip and compressional faults planes less common. Sandstone-filled normal faults (SFNF) are cm- to dm-wide, with small offsets, rarely developed shear zones and steeply-dipping attitude.

Sandstone-filled normal faults are well exposed at Bonny Doon and Laguna Creek beaches (Fig. 1). At Bonny Doon Beach, a series of N-S and NNW-SSE oriented SFNF form a conjugate set that dissect the Santa Cruz Mudstone (Fig. 5a); a thin mudstone interval forms a useful marker bed (Fig. 5b). The master fault consists of a high angle SFNF with a maximum thickness of $30 \mathrm{~cm}$ and a throw of $15 \mathrm{~cm}$. The entire exposure of the fault is propped open by a sandstone fill. A weak damage zone, consisting of closely-spaced fractures, occurs parallel to the fault margin. Unlike associated faults that are not intruded by sandstone and contain a fault gouge comprising cataclastic breccia and clay smear, the SFNF commonly lacks of fault gouge. 
This is a non-peer reviewed pre-print.

The Manuscript is currently under review in Marine and Petroleum Geology. Please note the subsequent version of this manuscript may have a different content.

At Laguna Creek Beach the outcrop has numerous normal fault planes that are characterised by intense cataclasis and clay smearing with occasional SFNF present. An almost vertical fault zone displays the $\sim 50 \mathrm{~cm}$ offset of a clay marker bed (Fig. $5 \mathrm{c}, \mathrm{d}$ ). The fault consists of two main fully-injected overlapping segments, which are connected by secondary en echelon linked fractures (Fig. 5e, f). Locally, these linked fractures have a sandstone fill. Most of deformation is confined between the two fault segments whereas the external areas have very little evidence of brittle deformation. The role played by these structures in the evolution of the Santa Cruz petroleum system, and the relationships between sandstone-filled faults and the other elements of the SCIC are discussed in detail later.

\subsection{Sand extrudites}

Remarkable exposure of several sand extrudites at Red, White and Blue Beach (Fig. 1) records at least three, and probably four, phases of sand extrusion onto a stacked series of paleo-seafloors (Fig. 6). They occur as tar-saturated, laterally-discontinuous, mounded sandstone units within the Santa Cruz Mudstone that are temporally and spatially distinct (Hurst et al., 2006). Extrudites extend over hundreds of meters, are meters thick, and consists of sand bodies that display a well-developed bed-parallel lamination or cross-bedding (Fig. $6 a, b)$. Locally, the original structure of sand volcanoes, which show multiple conduits and laminated flanks reaching inclinations approaching $30^{\circ}$, are still preserved. Planar basal surfaces are common, disturbed only by occasional sub-vertical "escape" burrows and, by the occurrence of sandstone-filled pockmarks. The pockmarks are underlain by dykes that terminate at the paleo-seafloor and are typically $<5 \mathrm{~m}$ across although one $>30 \mathrm{~m}$ wide pockmark is preserved, which is fed by numerous low- and high-angle to bedding dykes.

\section{Tectonic structures in the Santa Cruz area}


This is a non-peer reviewed pre-print.

The Manuscript is currently under review in Marine and Petroleum Geology. Please note the subsequent version of this manuscript may have a different content.

In order to investigate the relationships that exist between tectonic structures and sandstone intrusions, a detailed structural survey has been carried out in five key outcrop locations: Shark Fin Cove, Bonny Doon Beach, Laguna Beach, Panther Beach and 4 Mile Beach (Fig. 1c). Tectonic structures mainly consist of large-scale open folds, meso-scale faults, and dilatant fractures and joints. According to our observations and those of previous studies (Phillips, 1990), the structures are interpreted as a brittle expression of the Cenozoic tectonic deformation related to the San Gregorio and San Andreas faults (Fig. 1a, b).

\subsection{Folds}

Open anticlinal and synclinal folds with decametre to kilometre wavelength are recognised throughout the study area (Fig. 7a, b). They are characterised by gently-dipping limbs and fractured fold hinges. In outcrop, the fold hinge zone is often removed by erosion. Fold axes commonly display NW-SE trends and SE plunges, which is in general agreement with observations made by Phillips (1990) (Fig. 7c).

\subsection{Faults}

Sets of differently oriented faults are the most prominent tectonic feature recognised along the coastal sector (Fig. 8a). Normal faults are the most common fault type, while strikeslip and occasional reverse faults are less common.

In general, normal faults consist of conjugate sets with a master fault plane and a series of minor associated antithetic and synthetic faults and fractures. Usually, major structures have small offsets, ranging from a few centimetres to some metres, and form a graben-like geometry (Fig. 8b). The best exposures of normal faults are found at 4 Mile Beach, Laguna Creek Beach and Bonny Doon Beach (Fig. 8c). Normal fault kinematics are characterised by 
This is a non-peer reviewed pre-print.

The Manuscript is currently under review in Marine and Petroleum Geology. Please note the subsequent version of this manuscript may have a different content.

dip-slip oriented slickensides coupled with stratigraphic offsets. Fault zones are commonly marked by fault breccia, together with fine-grained cataclastic crushed material. Clay smear is locally observed along the fault planes where they cut clay-rich horizons (Fig. 8d).

In common with the normal faults, strike-slip (Fig. 8e, f) and reverse faults (Fig. 8g, h) are characterised by limited displacement and narrow fault zones are best exposed around 4 Mile and Bonny Doon beaches. Fault breccia is rarely present, although thin (cm-scale) cataclastic zones and striated fault planes occur locally.

Measurement of fault orientation at all locations allows us to identify several fault sets that display a range of orientations and kinematics. In general, conjugate sets of NNE-SSW, N-S, NNE-SSW and NE-SW trending faults consist of extensional faults, NW-SE and NNWSSE trending faults comprise dextral strike slip faults, and E-W and WNW-ESE trending structures have a less clear kinematic origin.

\subsection{Fractures}

Fractures form a pervasive network throughout the study area. In general, fracture density increases from centimetres to a few millimetres when approaching fault planes. Conversely, fractures are regularly distributed and more widely spaced (centimetres to a few tens of centimetres) in the intra-fault areas (Rizzo et al., 2017). Outcrops at 4 Mile and Panther beaches (Fig. 1) represent typical case study fracture scenarios for the studied area.

The cliff-line of 4 Mile Beach is an excellent location for the study of fracture geometry, and the interactions between fractures and sandstone intrusions. In particular, most of the outcrop consists of steep, vegetation-free walls and a series of raised, intertidal terraces that together provide an exceptional 'pseudo-three dimensional' outcrop. Fractures are generally connected by abutments (Y- or T- points sensu Manzocchi et al., 1998 and Manzocchi, 2002) or have cross-cutting relationships (Fig. 9a). Fracture length varies from a 
This is a non-peer reviewed pre-print.

The Manuscript is currently under review in Marine and Petroleum Geology. Please note the subsequent version of this manuscript may have a different content.

few centimetres to some decimetres, with an average length in the order of $20 \mathrm{~cm}$ (Rizzo et al., 2017). Fracture apertures average on the order of $3( \pm 2) \mathrm{mm}$. Linkages between different fractures occur by dilatational jogs, horsetail and, without any physical intersection, by means of en echelon arrays (Kim et al., 2004; Peacock et al., 2016). In cross-section, the fractures usually show X and S shaped geometries (Fig. 9b). Fracture meshes (Sibson, 1996) are also common (Fig. 9c). Observations of plumose structures with well-developed hackle fringes support the hypothesis that Mode I tensile fracturing is the main mechanism by which fractures opened. Local evidence for shear fracture mechanisms is provided by calcite-filled tension gashes. As fractures cross different lithologies, diffraction phenomena may occur. Commonly, tensional fractures are filled by a hydrocarbon residue of tar (Rizzo et al., 2017) (Fig. 9d), together with less common calcite infill (Fig. 9e). Fracture distribution at 4 Mile Beach has two major conjugate fracture sets trending NNW-SSE and NW-SE (Fig. 9f).

At Panther Beach (Fig. 1), closely-spaced fractures are well-exposed along a series of cliff sections that are similar to those at 4 Mile Beach. Here, the thick sandstone sill (Thompson et al., 2007; Scott et al., 2009) (Fig. 4a) shows a different style of fractures, with $\mathrm{X}$-shaped geometry and mm-thick deformation bands, that isolate rhomboidal segments of sandstone (Fig. 9g). Millimetre-scale offsets typify fracture intersections. Fractures either terminate along, or are deflected by, finer grained, clay-rich layers. The fracture distribution displays predominantly NNW-SSE-orientations, with NW-SE-oriented fractures also abundant, while NE-SW and E-W-striking trends are less evident (Fig. 9h).

\subsection{Origin of tectonic structures in the Santa Cruz area}

Studies of Pliocene-Quaternary tectonic structures in the San Francisco Bay area, which includes the Santa Cruz area, were performed by a number of authors (Wilcox et al., 1973; Aydin and Page, 1984; Page et al., 1998). Based on these studies, the orientations of the 
This is a non-peer reviewed pre-print.

The Manuscript is currently under review in Marine and Petroleum Geology. Please note the subsequent version of this manuscript may have a different content.

tectonic structures recognised in the study area are consistent with a "wrench tectonic" environment (Moody and Hill, 1956) developed under the control of the San Andreas (average azimuth $\mathrm{N} 324^{\circ}$ ) and the San Gregorio (average azimuth N341 ${ }^{\circ}$ ) dextral strike-slip fault zones (Aydin and Page, 1984; Phillips, 1990) (Fig. 1b). Orientations of tectonic structures measured in the Santa Cruz coastal area show a close similarity with those predicted by the model. However, comparison between outcrop fault orientations with those produced in laboratory experiments also identified some inconsistencies (Aydin and Page, 1984). Primarily, these inconsistencies are attributable to the orientation of tectonic structures not being the result of movement along a single major fault, but rather the result of different interacting major faults. Secondly, fault orientation also depends on the mechanical behaviour of the different lithologies undergoing deformation. Finally, fracture orientation is affected by crustal heterogeneity and rotation during progressive shear.

The main ranges of fault trends recognised in the Santa Cruz Coastal area are illustrated in Fig. 10. NW-SE and NNW-SSE trending faults are interpreted as conjugate sets of strike-slip faults developed parallel to the San Andreas and the San Gregorio fault zones, whereas NNE-SSW oriented strike slip faults correspond to the associated Riedel structures (Fig. 8e, f). NNW-SSE, N-S, NNE-SSW and NE-SW trending extensional faults are dilational step-overs between right-lateral faults (Fig. 8b, c).

Unlike extensional and strike slip faults, SW-NE and WSW-ENE trending contractional faults (Fig. 8g, h) are inconsistent with a wrench tectonic model. However, they could be an expression of compressional deformation connected with the development of the Santa Cruz homocline between the Ben Lomond Mountains and the San Gregorio Fault (Stanley, 1990). According to Phillips (1990), southwest-plunging folds may be related to differential compaction mechanisms between thick sedimentary beds of the Santa Margarita Sandstone and the overlying Santa Cruz Mudstone. 
This is a non-peer reviewed pre-print.

The Manuscript is currently under review in Marine and Petroleum Geology. Please note the subsequent version of this manuscript may have a different content.

Fracture orientations largely reflect the trends of the main faults. For example, at 4 Mile and Panther beaches (Fig. 9), most of the N-S, NNE-SSW and NE-SW oriented fractures are consistent with the dominant extensional fault trends throughout the area. Similarly, NNWSSE and NW-SE fracture orientations are consistent with the dextral strike-slip faults. The NE-SW trends could however be associated with outer-arc axial fracturing related to the folding phase. As fractures that accompany the emplacement of the sandstone intrusions are distributed along well-defined trends, we exclude a possible hydraulic fracturing origin that would typically show less constrained orientations.

\section{Relationships between sandstone intrusions and tectonic structures}

In the previous sections we described the main characteristics and spatial distribution of sandstone intrusions and tectonic structures occurring in the Santa Cruz coastal area. Field observations allowed us to recognise sandstone intrusions that are either related or unrelated to tectonic structures that are now discussed.

\subsection{Sandstone intrusions associated with tectonic structures}

Close relationships between sandstone intrusions and tectonic structures have already been ascertained by the recognition in the study area of sandstone-filled normal faults (Phillips, 1990; Palladino et al., 2018) (Fig. 5). This evidence clearly indicates that fluidised sand was driven along tectonic discontinuities. The influence of tectonics on the distribution of sandstone intrusions is evident when comparing dike orientations with fault and fracture patterns (Fig. 11). Although sandstone dikes are spatially more dispersed than the orientation of the major faults, their orientation follow broadly similar trends of NNW-SSE, N-S, SWNE and WSW-ENE, which are consistent with the average fault and fracture orientations. 
This is a non-peer reviewed pre-print.

The Manuscript is currently under review in Marine and Petroleum Geology. Please note the subsequent version of this manuscript may have a different content.

Notably, all dominant trends coincide with dilational structures. In particular, the majority of

NNW-SSE, N-S and SW-NE oriented structures are compatible with extensional faults, whereas WSW-ENE oriented structures likely coincide with outer-arc extension fractures related to folding (Fig. 7). A small number of injections coincide with strike slip or contractional faults in which dilation is commonly inhibited.

\subsection{Sandstone intrusions not associated with tectonic structures}

The occurrence of sandstone-filled faults and fractures noted above markedly contrasts with sandstone intrusions which are unrelated to tectonics (Thompson et al., 1999; Boehm and Moore, 2002, Scott et al., 2009). These intrusions are considered to be emplaced in propagating hydraulic fracture network systems that formed during periods of severe, sometimes supra-lithostatic, pore-fluid pressure in the very shallow crust (Hurst et al., 2011). These sand injections are clearly overprinted by tectonics and do not show intrusion-parallel fractures that would progressively increase toward dike margins, as expected for tectonicallyrelated intrusive geological bodies (Delaney et al., 1986). Evidence for tectonic overprint of sandstone intrusions are particularly well-exposed at 4 Mile Beach, Shark Fin Cove and Laguna Beach.

At 4 Mile Beach, saucer-shaped sandstone intrusions are intensely overprinted by closely-spaced fractures which are genetically associated with larger extensional faults (Fig. 12a, b). We found no evidence of hydrofracturing and polygonal faults (Cartwright et al., 2003; Vigorito et al., 2008; Vigorito and Hurst, 2010) that are generally invoked as the mechanism which accommodates the emplacement of sandstone intrusions in sedimentary basins unaffected by tectonic deformation. Fractures systematically cut through the sandstone intrusions and continue into the host strata, indicating that the deposits were well-lithified at the time when tectonic deformation occurred. 
This is a non-peer reviewed pre-print.

The Manuscript is currently under review in Marine and Petroleum Geology. Please note the subsequent version of this manuscript may have a different content.

Of particular interest, is the $1.5 \mathrm{~m}$ thick sandstone dike cropping out in three adjacent locations at Shark Fin Cove (Fig. 12c). At two of the locations, the dike has planar margins, sharp contacts with the host strata, and no evidence of dike-parallel fracturing or mechanical brecciation, as typically associated with a fault plane (Fig. 12d). By contrast, at the third outcrop, the dike is significantly affected by post-emplacement deformation (Fig. 12e). In this case, deformation is concentrated along the dike margins, resulting in their reactivation. Occurrence of slickensides along the dike surfaces adds support to this interpretation. Here, stress concentration is accommodated differently by the mudstone and sandstone: in the brittle mudstone, deformation caused pervasive, intense fracturing that produced chaotic finegrained cataclastic material; in the sandstone, deformation produces conjugate, widely-spaced fracture sets (Fig. 12f).

A 1.5 m wide dike at Laguna Beach (Fig. 1) has evidence of post-emplacement vertical compression associated with regional extensional faulting (Fig. 12g). Consequently, we can interpret the observed conjugate fractures and shear surfaces that dip at $45^{\circ}$ from the vertical (Fig. $12 \mathrm{~h}$ ) as structures formed by a vertical maximum principle stress $\left(\sigma_{1}\right)$ that acted upon the poorly-consolidated sandstone. Prevailing arrays of NW-dipping shear planes caused the partial sinistral offset of the dike (Fig. 12h). In the mudstone host strata, brittle deformation mostly formed fractures, whereas in the sandstone deformation was accommodated mainly through conjugate deformation bands, with millimetres to centimetres offsets. When crossing the boundary separating the host strata from the dike, tectonic discontinuities are often refracted.

\subsection{Cross-cutting relationships}


This is a non-peer reviewed pre-print.

The Manuscript is currently under review in Marine and Petroleum Geology. Please note the subsequent version of this manuscript may have a different content.

Assuming a relatively synchronous faulting event in the Santa Cruz area, then the critical observations are: a) faults and associated fractures overprint and deform pre-existing sandstone intrusions, and, b) sand is injected along fault and fracture planes. These relationships make it unlikely that the SCIC was built during a single-stage emplacement event. Rather, the data shown in this work demonstrate that the present architecture of the SCIC results from distinct emplacement events. It follows that, two contrasting styles of sand injection are recorded in the Santa Cruz area, an earliest associated with hydraulic fracturing in the very shallow crust ( $<250 \mathrm{~m}$ burial, Vigorito and Hurst, 2010), that was followed by a later injection event guided by tectonics, cross-cutting the earlier intrusions suites. The same brittle deformation phase caused the definitive failure of the hydrocarbons top seal.

The early sandstone intrusions form an assorted suite consisting of both high and lowangle dikes, sills and saucer-shaped sandstone intrusions (Fig. 4). This event is recorded by several extrudites, whose origin is related to different pulses of sand mobilisation identified at different stratigraphic levels in the succession (Hurst, 2006) (Fig. 6). The second generation of sandstone intrusions is emplaced along pre-to-syn-tectonic structures,

Clear cross-cutting relationships between the two recognised generations of sandstone intrusions are well-exposed at Panther Beach (Fig. 13). Here, in the south-eastern side of the beach, the first generation of sandstone intrusions is cut by sandstone-filled faults (Fig. 13a). The outcrop consists of a cliff made of diatomaceous mudstone hosting a $10 \mathrm{~cm}$ thick, tarsaturated, low-angle dike belonging to the first generation of sandstone injections (Fig 13b). The dike has a reasonably constant lateral thickness, internal sedimentary structures, as well as bed-parallel mm-thick banding and no evidence of hydrofracturing associated with its emplacement. The dike is repeatedly cut by a series of conjugate sandstone-filled normal faults (Fig. 13c) showingffsets of a few centimetres. 
This is a non-peer reviewed pre-print.

The Manuscript is currently under review in Marine and Petroleum Geology. Please note the subsequent version of this manuscript may have a different content.

One of the through-going faults named Fault 1 (Fig. 13b), visible on the right-hand side of the outcrop, offsets the low-angle dike by about $10 \mathrm{~cm}$. A closer caption of the fault plane (Fig. 13d) highlights a very complex geometry; it mainly consists of several fault planes connected by linking damage zones here represented by extensional fractures and dilatational jogs. Locally, these structures are filled by the sand which is likely to have been produced by the partial fluidisation of the faulted sand bodies. Where the fault intercepts the marker bed, the latter appears stretched and thinned rather than sharply cut by the tectonic structure. We can identify three different zones along the faulted dike. In the inner zone (Fig. 13 e, f), in the proximity of the fault plane, the sand is structureless and contains floating clasts derived from the host strata. This characteristic indicates that fluidization processes predominantly occurred during faulting in this portion. In the intermediate zone (Fig. 13 e, f), the dike is largely affected by fracturing (in a conjugate geometry) which overprints the original banding. Such features suggest that in this zone, the sand composing the dike was able to retain the tectonic structures and was not fluidised at the time of the deformation. In the external zone (Fig. 13 e, f), the lack of deformation structures and the occurrence of well-preserved bed-parallel banding indicates that this zone was unaffected by deformation. This lateral distribution clearly suggests that the faulted sandstone dike behaves in a progressively more ductile manner approaching the fault plane. In contrast, the host rock shows a brittle behaviour as testified by the occurrence of pervasive fractures.

A second fault zone, named Fault 2 (Fig. 13g.), clearly offsets the low-angle dike however with a different deformation style compared to Fault 1. In this case there are no evidence of ductile deformation and sand remobilisation along the exposed section. However, syn/post-faulting sandstone intrusions occurred along a series of en echelon dilation fractures associated with the main fault plane (Fig. 13h, i). In this case, the fluidised sand might have been generated in distant portions of the fault and be laterally transported along dilational jogs. 
This is a non-peer reviewed pre-print.

The Manuscript is currently under review in Marine and Petroleum Geology. Please note the subsequent version of this manuscript may have a different content.

The last fault zone, named Fault 3 (Fig. 13k), consists of a steeply-dipping normal fault discontinuously filled by tar-saturated sandstone. The fault plane shows a stepped geometry and sandstone intrusions mainly occur in correspondence with releasing steps which form lozenge-shaped cavities (Fig. 131). Sandstone intrusions are also present along vertical fractures and minor fault planes associated with the main structure. The sandstone-filled structure cuts the low-angle dike and the offset is about $10 \mathrm{~cm}$.

\section{Discussion}

Previous attempts to comprehend both the potential of the Santa Cruz petroleum system (SCPS) and the distribution of the local paleo-stress have led to studies focussing on the organization of the SCIC, and the relationships between the sandstone intrusions and tectonic structures (Clark, 1981; Phillips, 1981; 1990; Thompson et al., 1999; Boehm and Moore, 2002). In most of these studies, the regional tectonic stresses were inferred to control the emplacement of sand injections, which, in turn, influenced hydrocarbon accumulation. Field observations clearly reveal that, in places, dikes are intruded along faults. Phillips (1981; 1990) originally noticed the correspondence between fault and dike orientations, and therefore suggested that the emplacement of sandstone intrusions was mainly related to tectonic processes. Later, Thompson et al. (1999) confirmed the occurrence of sand injections along faults and fractures, however he also observed episodes of faulting that post-date sandstone intrusion at Yellowbank Creek. Boehm and Moore (2002) recognised a predominant NE-SW trend for the Santa Cruz sandstone intrusions, thus supporting the hypothesis of a strong tectonic control for sand injections. Similar to Thompson et al. (1999), they also provided evidence of faulting and fracturing that post-dates the sand injections. However, Boehm and Moore (2002) described a mechanical inconsistency represented by the emplacement of northeast-striking dikes, which would require a NW-SE minimum principal stress orientation $\left(\sigma_{3}\right)$, 
This is a non-peer reviewed pre-print.

The Manuscript is currently under review in Marine and Petroleum Geology. Please note the subsequent version of this manuscript may have a different content.

and the simultaneous intrusion of sills, which suggests a sub-vertical minimum principal stress. The authors solved the apparent inconsistency proposing a model where dikes intruded perpendicularly to the NW-SE oriented $\sigma_{3}$, and simultaneously weak sediment cohesion of the host rock allowed sills to be emplaced parallel to bedding (i.e. pre-existing bedding-parallel weakness). Notably, these previous works considered the emplacement of the SCIC to be the result of a single injection event.

Based on the data presented in the previous sections, in particular on the detailed crosscutting relationships, it is possible to explain the inconsistencies raised by Boehm and Moore (2002) in terms of a model involving two separate phases of sand injection from the Upper Miocene onwards (Fig. 14). Although these two events involved the same stratigraphic unit, i.e. the Santa Cruz Mudstone, the mechanical response of the sedimentary sequence and the regional tectonic controls varied between the two injection events thereby resulting in sandstone intrusions displaying different characteristics.

The first injection event (Fig. 14a) caused the partial fluidisation of the Santa Margarita Sandstone and the emplacement of a significant volume of remobilised sand into the overlying top seal unit represented by the Santa Cruz Mudstone. This injection event mainly led to the emplacement of sills, saucer-shaped intrusions and some low-angle dikes as seen at 4 Mile Beach and Panther Beach (Fig. 4). Isolated dikes locally connected flat-lying sandstone intrusions positioned at different stratigraphic levels in the Miocene succession.

The energy released during this event was large enough to create fluid-pressure gradients between buried sand bodies and the basin floor. This resulted in the development of a complete sand injection complex, spanning from remobilised parent units, intrusive elements to extrudites (Scott et al., 2009; Vigorito and Hurst, 2010). Sills and saucer-shaped intrusions were emplaced at the depth where the vertical pore-fluid pressure gradient is equal 
This is a non-peer reviewed pre-print.

The Manuscript is currently under review in Marine and Petroleum Geology. Please note the subsequent version of this manuscript may have a different content.

to, or exceeds the overburden pressure, resulting in the minimum principal stress $\left(\sigma_{3}\right)$ being vertical.

Evidence for this first top seal failure event, and initiation of the sand injection complex, are provided by the internally-stacked, sheet or mounded sandstones at Red and White Blue Beach (Fig. 1), which are interpreted as extrudites (Boehm and Moore, 2002; Hurst et al., 2006). The series of three or four periods of extrusion are implicitly, and in some cases visibly, associated with underlying sand injection complexes that occurred during periods of otherwise fine-grained sedimentation, typically dominated by biosiliceous silica throughout the Late Miocene. The cyclic occurrence of extrudites in the mudstone succession reflects the alternating episodes of overpressure build-up and its subsequent release. In the field, no evidence for hydraulic fracturing attributable to this first event has been recognised. The lack of fractures is possibly related to the host strata still being poorly consolidated at the time of sand injection. If any fracture network did develop at this time, it behaved as a valve for the temporary passage of fluids and fluidised sands, thereby allowing overpressure to be dissipated. However, due to the unconsolidated state of the host unit, fractures were likely resealed soon after the sand emplacement thereby allowing the successive accumulation of hydrocarbon in the SCPS (Fig. 14b). In addition, once Opal A/Opal CT transformation involved the Santa Cruz Mudstone (El-Sabbagh and Garrison, 1990), most of the remaining fractures disappeared obliterating evidence of hydraulic fracturing processes.

Several factors, in addition to rapid burial and regional tectonics, may have contributed to the build-up of the necessary fluid pressure. According to laboratory experiments (Galland et al., 2003) (Fig. 2), the occurrence of flat-lying sandstone intrusions, as well as sill and saucer-shaped intrusions indicates the absence of oriented tectonic stresses, or, more probably, the development of a horizontal maximum principal stress which led to the folding of the Miocene succession. According to Phillips (1990), differential compaction and compressional 
This is a non-peer reviewed pre-print.

The Manuscript is currently under review in Marine and Petroleum Geology. Please note the subsequent version of this manuscript may have a different content.

tectonics created folding suitable for hydrocarbon migration and accumulation. This event 604 605 606 607 608 609 610 could have also triggered sandstone injections as many intrusions are concentrated along the crest of the anticlines (Thompson et al. 1999; Boehm and Moore, 2002). In this context, sand injections cropping out at Major Creek (Fig. 1), one of the most extensive injected sand bodies and previously exploited for tar mining, corresponds with the crest of a major SW-plunging anticline.

Following this event, the system resealed, and the depositional and injected sandstones collectively created a permeable network allowing further hydrocarbon accumulation.

The second injection event (Fig. 14c) caused sand fluidisation and remobilization of both the Santa Margarita Sandstone and the previously injected sandstone intrusions. The new sand injections mainly consist of a series of high angle dikes, emplaced along extensional faults and fractures, consistently following the trend of the San Andreas/San Gregorio fault system (Fig. 8), cutting through the Santa Cruz Mudstone that were by this time fully lithified. The sudden failure and re-opening of the system caused a rapid fluid transfer from the underlying overpressured units into the newly-formed structures, according to the mechanism proposed by Palladino et al. (2018). Sandstone-filled faults and brittle deformation accompanying this injection phase clearly post-date sandstone intrusions created during the first event (Fig. 13). We then suggest that this fault system reached the basin floor or the topographic surface breaking the top seal and triggering the consequent leak of the hydrocarbons. This chain of events is documented by the widespread occurrence of tarsaturated sandstones and fractures currently observed at Santa Cruz. Extrudites may also have been produced during this event but, unfortunately, recent erosional surfaces (Weber and Allwardt, 2001) cut the studied outcrops, and do not allow a precise age constraint for this faulting/injection event. 
This is a non-peer reviewed pre-print.

The Manuscript is currently under review in Marine and Petroleum Geology. Please note the subsequent version of this manuscript may have a different content.

628

629

630

631

632

633

634

635

636

\section{Conclusions}

The acquisition of detailed structural data, together with observations of the relationships between the existing sedimentary and tectonic elements, allow us to unravel the evolutionary history of the Santa Cruz petroleum system (SCPS) in Central California. In particular, the evolution of the Santa Cruz petroleum system has been characterised by multiple episodes of sandstone intrusions by the Late Miocene onwards, which lead to emplacement of the Santa Cruz Injection Complex (SCIC). In this study sand injection episodes have been grouped into two main phases:

- During the first phase, the partial failure of the top seal, the Santa Cruz Mudstone, lead to the emplacement of a series of sills, saucer-shaped intrusions and dikes under the control of compaction and compressional tectonic processes. The new added sand enhanced the permeability of the Santa Cruz Mudstone and allowed hydrocarbon accumulation. The lack of brittle deformation features associated with this first event testifies that sand injection occurred in a poorly consolidated host rock (i.e. the Santa Cruz Mudstone) and that the fractures resealed soon after sand emplacement. The healing of the fracture system enabled the accumulation and entrapment of hydrocarbons, building of the Santa Cruz petroleum system. Sandstone extrudites allows us to attribute this event to the Late Miocene.

The second phase of the sand injection was closely associated with brittle tectonic events, as well supported by the sand bodies emplaced along high-angle extensional faults. Brittle deformation accompanying this event indicates that sand injection occurred in wellconsolidated host strata. This event, whose age is still uncertain, although it ranges between the Late Miocene to Quaternary, caused the breaching of the seal and the leaking of the hydrocarbons previously accumulated in the Santa Cruz petroleum system. Most of the deformation is accommodated via normal faulting and widespread fracturing, whose trends are consistent with a wrench tectonic geometry compatible with the regional tectonic settings. 
This is a non-peer reviewed pre-print.

The Manuscript is currently under review in Marine and Petroleum Geology. Please note the subsequent version of this manuscript may have a different content.

653

\section{Acknowledgements}

We acknowledge the support of sponsoring companies of Phase 3 of the Sand Injection

Research Group (SIRG). We are very grateful to David Iacopini for the critical review of the

paper. We also wish to thanks Denis Bureau and Antonella Gatto for the support in the field.

658

659

References

660

Atwater, T., Stock, J., 1998. Pacific-north America plate tectonics of the Neogene southwestern United States: an update. Int. Geol. Rev. 40, 375-402.

663

Aydin, A., Page, B.M., 1984. Diverse Pliocene-Quaternary tectonics in a transform 665 environment, San Francisco Bay region, California. GSA Bulletin 95, 1303-1317.

Barron, J.A., 1986. Paleoceanographic and tectonic controls on deposition of the Monterey 668 Formation and related siliceous rocks in California. Palaeogeography, Palaeoclimatology, Palaeoecology 53, 27-45.

670

Boehm, A., Moore, J.C., 2002. Fluidized sandstone intrusions as an indicator of paleostress orientation, Santa Cruz, California. Geofluids 2, 147-161.

673 
This is a non-peer reviewed pre-print.

The Manuscript is currently under review in Marine and Petroleum Geology. Please note the subsequent version of this manuscript may have a different content.

677 Bradley, W.C., Griggs, G.B., 1976. Form, genesis, and deformation of central California 678 wave-cut platforms. Geological Society of America Bulletin 87, 433-449.

679

680 Bürgmann, R., Arrowsmith, R., Dumitru, T., McLaughlin R., 1994. Rise and fall of the 681 southern Santa Cruz Mountains, California, from fission tracks, geomorphology, and geodesy. 682 J. Geophys. Res. 99, 20181-20202, doi:10.1029/94JB00131.

683

684 Cartwright, J., James, D. \& Bolton, A., 2003. The genesis of polygonal fault systems: a review, 685 in: Van Rensberger, P., Hillis, R.R., Morley, C.K. (Eds.), Subsurface Sediment Mobilization. 686 Geological Society, London, Special Publications 216, 223-243.

687

688 Cartwright, J.A., Huuse, M., Aplin, A., 2007. Seal bypass systems. AAPG Bulletin 91, 1141$689 \quad 1166$.

690

691 Clark, J.C., Rietman, J.D., 1973. Oligocene stratigraphy, tectonics, and paleogeography 692 southwest of the San Andreas fault, Santa Cruz Mountains and Gabilan Range, California 693 Coast Ranges: U.S. Geological Survey Professional Paper 783, 18 p.

694

695 Clark, J.C., 1981. Stratigraphy, palaeontology, and geology of the central Santa Cruz 696 Mountains, California Coast Range: U.S. Geological Survey Professional paper 1168, p. 51.

697

698 Delaney, P.T., Pollard, D.D., Ziony J.I., McKee E.H., 1986. Field relations between dikes and 699 joints emplacement processes and paleostress analysis. Journal of Geophysical Research 91, $700 \quad 4920-4938$. 
This is a non-peer reviewed pre-print.

The Manuscript is currently under review in Marine and Petroleum Geology. Please note the subsequent version of this manuscript may have a different content.

Dickinson, W.R., Ducea, M., Rosenberg, L.I., Greene, H.G., Graham, S.A., Clark, J.C., Weber, G.E., Kidder, S., Ernst, W.G., Brabb, E.E., 2005. Net dextral slip, Neogene San Gregorio-Hosgri fault zone, coastal California: Geologic evidence and tectonic implications: Geological Society of America Special Paper 391, 43 p.. doi: 10.1130/2005.2391.

Dixon, R.J., Schofield, K., Anderton, R., Reynolds, A.D., Alexander, R.W.S., Williams, M.C., Davies, K.G., 1995. Sandstone diapirism and clastic intrusion in the Tertiary submarine fans of the Bruce-Beryl Embayment, Quadrant 9, UKCS, in: Hartley, A.J., Prosser, D.J. (Eds.), Characterisation of deep-marine clastic systems: Geological Society, London Special Publication 94, 77-94.

Duranti, D., Hurst, A., Bell, C., Groves, S., Hanson, R. 2002. Injected and remobilised Eocene sandstones from the Alba Field, UKCS: core and wireline log characteristics. Petrol. Geosci. 8, 99-107.

Duranti, D., Hurst, A., 2004. Fluidization and injection in the deep-water sandstones of the Eocene Alba formation (UK north Sea). Sedimentology 51, 503-529.

Eldridge, G.H., 1901. The asphalt and bituminous rock deposits of the United States: U.S. Geological Survey Ann. Rept. 22, pt. 1, 209-464.

El-Sabbagh, D., Garrison, R.E., 1990. Silica digenesis in the Santa Cruz Mudstone (Upper Miocene), La Honda Basin, California, in: Garrison, R.E., Greene, H.G., Hicks, K.R., Weber G.E., Wright T.L. (Eds.), Geology and Tectonics of the Central California Coast Region, San 
This is a non-peer reviewed pre-print.

The Manuscript is currently under review in Marine and Petroleum Geology. Please note the subsequent version of this manuscript may have a different content.

Francisco to Monterey, Volume and Guidebook, Pacific Sec. Assoc. Amer. Petrol. Geol., 123132.

Ferre', E.C., Galland, O., Montanari, D., Kalakay, T.J., 2012. Granite magma migration and emplacement along thrusts. Int. J. Earth Sci. Geol. Rundschau Springer. http://dx.doi.org/10.1007/s00531-012-0747-6.

Galland, O., De Bremond d'Ars, J., Cobbold, P.R., Hallot, E., 2003. Physical models of magmatic intrusion during thrusting. Terra Nova 15, 405-409.

Galland, O., Cobbold, P.R., De Bremond d'Ars, J., Hallot, E., 2007. Rise and emplacement of magma during horizontal shortening of the brittle crust: insights from experimental modelling. J. Geophys. Res. 112, B06402. http:// dx.doi.org/10.1029/2006JB004604.

Hallmark, R.O., 1980. Unconventional petroleum resources in California: Calif. Div. Oil and Gas Pub. TR25, 17 p.

Heck, R.G., Edwards, E.B., Kronen, J.D., Jr., Willingham, C., 1990. Petroleum potential of the offshore outer Santa Cruz and Bodega basins, California, in: Garrison, R.E., Greene, H.G., Hicks, K.R., Weber, G.E., Wright, T.L. (Eds.), Geology and tectonics of the Central California Coast Region-San Francisco to Monterey. American Association of Petroleum Geologists, Pacific Section, Calif., 143-163. 
This is a non-peer reviewed pre-print.

The Manuscript is currently under review in Marine and Petroleum Geology. Please note the subsequent version of this manuscript may have a different content.

749 Hosford Scheirer, A., Magoon, L.B., Graham, S.A., 2013. Petroleum Systems of the Santa 750 Cruz County Coast, California. AAPG Search and Discovery Article, Pacific Section AAPG, 751 SPE and SEPM Joint Technical Conference, Monterey, California.

Hurst, A., Cartwright, J.A., Duranti, D., Huuse, M., Nelson, M., 2005. Sand injectites: an emerging global play in deep-water clastic environments, in: Doré, A., Vining, B. (Eds.), Petroleum Geology: North-west Europe and Global Perspectives. Proceedings of the $6^{\text {th }}$ Petroleum Geology conference. Geological Society, London, 133-144.

Hurst, A., Cartwright, J.A., Huuse, M., Duranti, D., 2006. Extrusive sandstones (extrudites): a new class of stratigraphic trap?, in: Allen, M.R., Goffey, G.R, Morgan, R.K., Walker, I.M. Publications 254, 289-300.

Hurst, A., Scott, A., Vigorito, M., 2011. Physical characteristics of sand injectites. Earth Sci. Rev. 106, 215-246. target. AAPG Bulletin 101, 625-633.

Huuse, M.J., Cartwright, J.A., Hurst, A., Steinsland, N., 2007. Seismic characterization of large-scale sandstone intrusions, in: Hurst, A., Cartwright, J. (Eds.), Sand Injectites: 
This is a non-peer reviewed pre-print.

The Manuscript is currently under review in Marine and Petroleum Geology. Please note the subsequent version of this manuscript may have a different content.

Jackson, C.A.L., Huuse, M., Barber, G.P., 2011. Geometry of wing-like intrusions adjacent to a deep-water slope channel complex and implications for hydrocarbon exploration and production: a 3D seismic case from the Maloy Slope, offshore Norway. AAPG Bull. 95, 559584.

Jenkins, O.P., 1930. Sandstone dikes as conduits for oil migration through shales. AAPG Bull. $14,411-421$

Jolly, R.J.H., Lonergan, L., 2002. Mechanisms and controls on the formation of sand intrusions. J. Geol. Soc. Lond. 159, 605-617.

Kim, Y., Peacock, D.C.P., Sanderson, D.J., 2004. Fault damage zones. J. Struct. Geol. 26, 503-517.

Lillis, P.G., Stanley, R.G., 1999. Petroleum systems of the La Honda Basin, California. AAPG Bulletin 83, 694-694.

Lowe, D.R., 1975. Water escape structures in coarse-grained sediments. Sedimentology 22, $157-204$.

Manzocchi, T., Ringrose, P.S., Underhill, J.R., 1998. Flow through fault systems in highporosity sandstones, in: Coward, M.P., Daltaban, T.S., Johnson, H. (Eds.), Structural Geology in Reservoir Characterization. Geological Society, London, Special Publications 127, 65-82. 
This is a non-peer reviewed pre-print.

The Manuscript is currently under review in Marine and Petroleum Geology. Please note the subsequent version of this manuscript may have a different content.

Manzocchi, T., 2002. The connectivity of two-dimensional networks of spatially correlated

fractures, Water Resour. Res. 38, 1162. doi:10.1029/2000WR000180

800

Molyneux, S., 1999. Giant clastic dykes and sills of Santa Cruz, Coastal California. Petroleum

Exploration Society of Great Britain, Newsletter, 118-125.

803

Moody, J.D; Hill, M.J., 1956. Wrench-fault tectonics. GSA Bulletin 67, 1207-1246.

805

Mullins, H.T., Nagel, D.K., 1982. Evidence for shallow hydrocarbons offshore northern Santa

Cruz County, California. Bull. Am. Assoc. Pet. Geol. 66, 1130-1140.

808

Newsom, J.F., 1903. Clastic dikes. Geological Society of America Bulletin 14, 227-268.

810

Page, B.M., Holmes, C.N., 1945. Geology of the bituminous sandstone deposits near Santa

Page, B.M., Thompson, G.A., Coleman, R.G., 1998. Late Cenozoic tectonics of the central and southern coast ranges of California. Geol. Soc. Am. Bull. 110, 846-876. 
This is a non-peer reviewed pre-print.

The Manuscript is currently under review in Marine and Petroleum Geology. Please note the subsequent version of this manuscript may have a different content.

Peacock, D.C.P., Nixon, C.W., Rotevatn, A., Sanderson, D.J., Zuluaga, L.F., 2016. Glossary of fault and other fracture networks. Journal of Structural Geology 92, 12-29.

Phillips, R.L., 1981. Depositional and structural controls on heavy-petroleum tar sands in Santa Cruz Mountains. AAPG Bull. 65. p. 970.

Phillips, R.L., 1990. Depositional and structural controls on the distribution of tar sands in the Santa Cruz mountains, California, in: Garrison, R, Greene, H.G., Hicks, K.R., Weber, G.E., Wright, T.L. (Eds.), Geology and Tectonics of the Central California Coastal Region, San Francisco to Monterey, Volume and Guidebook, Pacific Section, American Association of Petroleum Geologists, Pacific Section, Bakersfield, CA, Book GB67, 105-21.

Phizackerley, P.H., Scott, L.O., 1978. Major tar-sand deposits of the world, in: Chilingarian, G.V., (Ed.), Bitumens, Asphalts, and Tar Sands, 57-92.

Rizzo, R.E., Healy, D., De Siena, L., 2017. Benefits of maximum likelihood estimators for fracture attribute analysis: Implications for permeability and up-scaling. Journal of Structural Geology 95, 17-31. 
This is a non-peer reviewed pre-print.

The Manuscript is currently under review in Marine and Petroleum Geology. Please note the subsequent version of this manuscript may have a different content.

Scott, A., Vigorito, M., Hurst, A., 2009. The process of sand injection: internal structures and relationships with host strata (Yellowbank Creek Injectite Complex, California, U.S.A.). Journal of Sedimentary Research 79, 568-583.

Scott, A., Hurst, A., Vigorito, M., 2013. Outcrop-based reservoir characterization of a kilometer-scale sand-injectite complex. AAPG Bull. 97, 309-343.

Sherry, T.J., Rowe, C.D., Kirkpatrick, J.D., Brodsky, E.E., 2012. Emplacement and dewatering of the world's largest exposed sand injectite complex. Geochemistry, Geophysics, Geosystems 13, 1-17.

Sibson, R.H., 1996. Structural permeability of fluid-driven fault-fracture meshes. Journal of Structural Geology 18, 1031-1042.

Stanley, R.G., McCaffrey, R., 1983. Extent and offset history of the Ben Lomond Fault, Santa Cruz County, California, In: Andersen, D.W., Rymer, M.J. (Eds.), Tectonics and Sedimentation Along Faults of the San Andreas System. SEPM-Society of Economic Paleontologists and Mineralogists, Los Angeles, California, 79- 90.

Stanley, R.G., 1990. Evolution of the Tertiary La Honda Basin, central California, in: Garisson, R.E. et al. (Eds.), Geology and Tectonics of the Central California Coastal Region, San Francisco to Monterey, Guidebook, Am. Assoc. of Pet. Geol., Bakersfield, Calif., 67, 129. 
This is a non-peer reviewed pre-print.

The Manuscript is currently under review in Marine and Petroleum Geology. Please note the subsequent version of this manuscript may have a different content.

Thompson, B.J., Garrison, R.E., Moore, J.C., 1999. A late Cenozoic sandstone intrusion west of Santa Cruz, California: Fluidized flow of water- and hydrocarbon saturated sediments, in: Garrison, R.E. Aiello I.W., Moore, J.C. (Eds.), Late Cenozoic fluid seeps and tectonics along the San Gregorio fault zone in the Monterey Bay region, California: Pacific Section AAPG Volume and Guidebook GB-16, p. 53-74.

Thompson, B.J., Garrison, R.E., Moore, C.J., 2007. A reservoir-scale Miocene Injectite near Santa Cruz, California, in: Hurst, A., Cartwright, J. (Eds.), Sand Injectites: Implications for Hydrocarbon Exploration and Production: American Association of Petroleum Geologists, Memoir 87, 151-162.

Vigorito, M., Hurst, A., Cartwright, J., Scott, A., 2008. Regional-scale shallow crustal remobilization: processes and architecture. Geol. Soc. Lond. Spec. Publ. 165, 609-612.

Vigorito, M., Hurst, A., 2010. Regional sand injectite architecture as a record of pore pressure evolution and sand redistribution in the shallow crust: insights from the Panoche Giant Injection Complex, California. J. Geol. Soc. Lond. 167, 889-904.

Weber, G.E., Allwardt, A.O., 2001. The geology from Santa Cruz to Point Año Nuevo: The San Gregorio fault zone and Pleistocene marine terraces: U.S. Geological Survey Bulletin, 2188, p. 1-32.

Wilcox, R.E., Harding, T.P., Seely, D.R. 1973. Basic Wrench Tectonics. AAPG Bulletin 57, 74-96. 
This is a non-peer reviewed pre-print.

The Manuscript is currently under review in Marine and Petroleum Geology. Please note the subsequent version of this manuscript may have a different content.

Figures

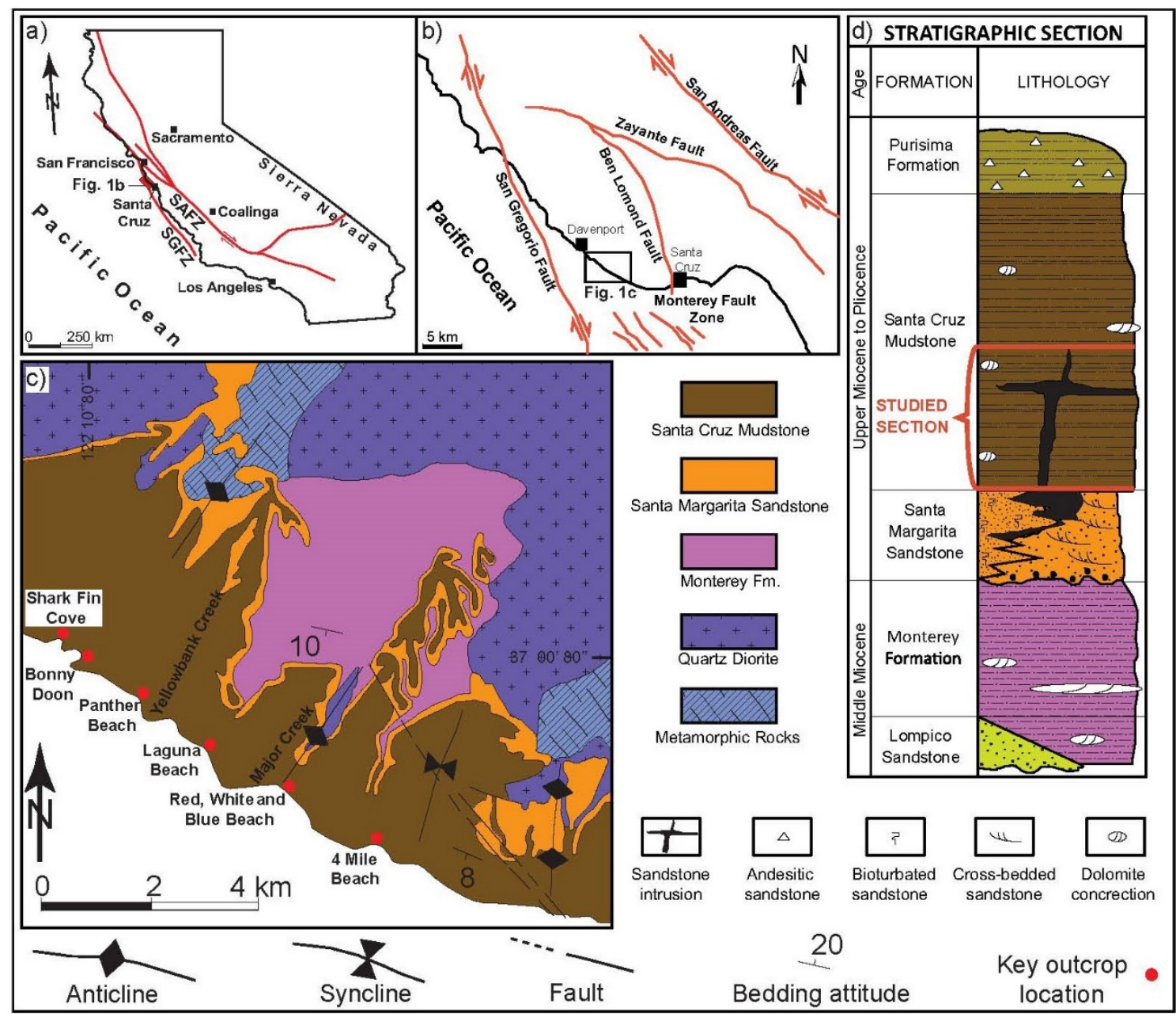

Fig. 1 a) Sketch map of California including the location of the study area (red box) and the main tectonic structures represented by the San Andreas Fault Zone (SAFZ) and the San Gregorio Fault Zone (SGFZ). b) Schematic structural map. The study area is included between the Ben Lomond and the San Gregorio fault zones. c) Geological map of the study area (modified from Boehm and Moore, 2002). Outcrop locations and places referred to in the text are also shown. d) Stratigraphic column of the geological units cropping out in the Santa Cruz coastal area (modified from Boehm and Moore, 2002). 
This is a non-peer reviewed pre-print.

The Manuscript is currently under review in Marine and Petroleum Geology. Please note the subsequent version of this manuscript may have a different content.

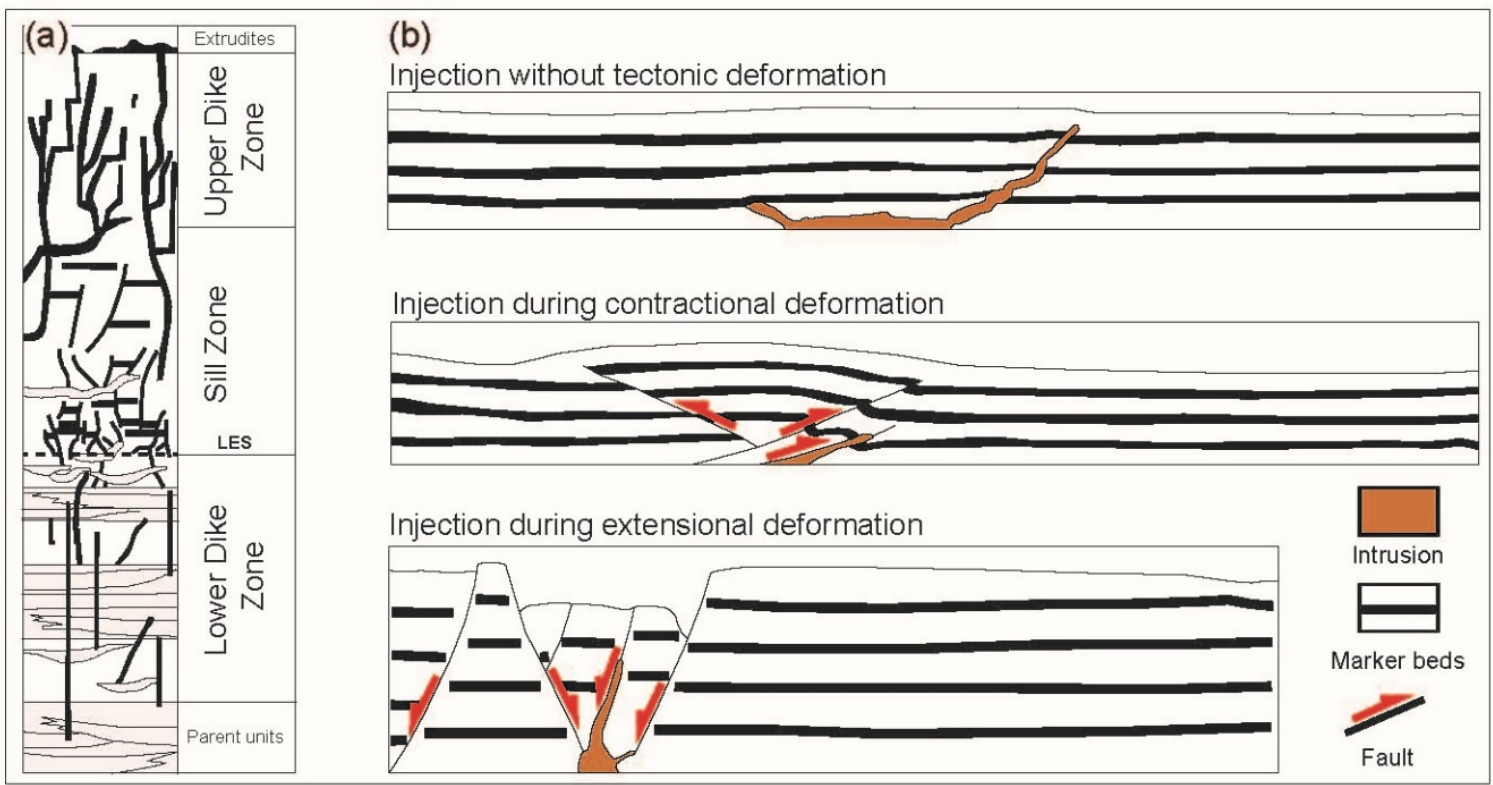

905 Fig. 2 a) Schematic organization of a sandstone intrusion complex following Vigorito and

906 Hurst (2010). Dikes mainly occur in the lower and upper portion of the sequence. Sills are 907 common in the middle portion. b) Possible geometry obtained for tectonically-unrelated and 908 tectonically-controlled intrusions from laboratory experiments (modified from Galland et al., 909 2007). 
The Manuscript is currently under review in Marine and Petroleum Geology. Please note the subsequent version of this manuscript may have a different content.

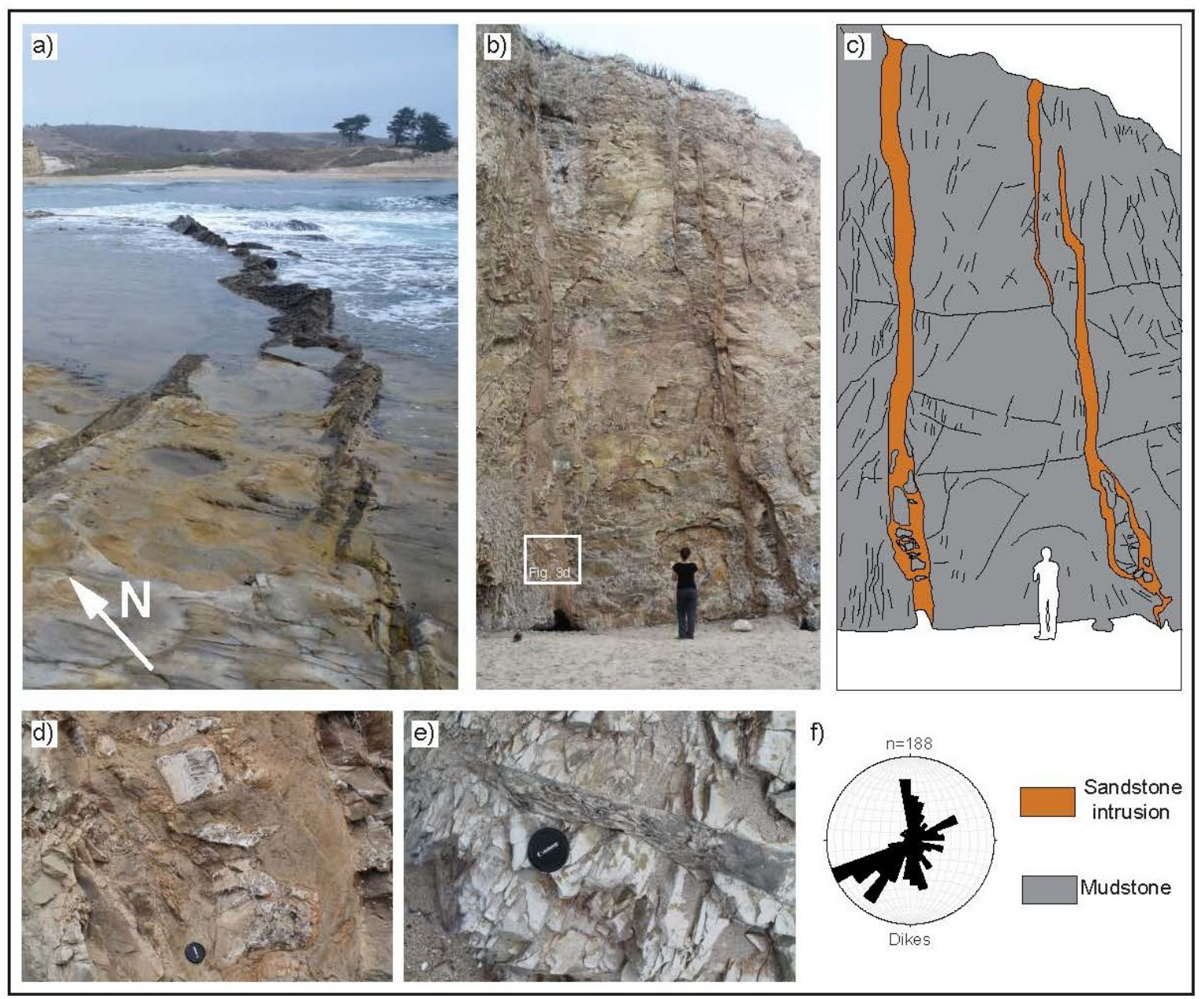

Fig. 3. Main characteristics of the dikes forming the SCIC. a) Bifurcating dike exposed at low tide in 4 Mile Beach. b) Photograph and interpretative line drawing (c) of dike swarm observable at Bonny Doon Beach. Note the local side-stepping geometry and the occurrence of decimetre to metre scale mud-clasts. d) Close up view of mud-clasts contained in the previous dike. e) Cm-scale mud-clasts contained in a tar saturated dike at Bonny Doon Beach. Note the clast orientation probably acquired during emplacement of the sandstone intrusion. f) Rose diagram showing dike orientations in the Santa Cruz coastal area. Preferential N-S, WSW-ENE and SW-NE trends are evident. 
This is a non-peer reviewed pre-print.

The Manuscript is currently under review in Marine and Petroleum Geology. Please note the subsequent version of this manuscript may have a different content.

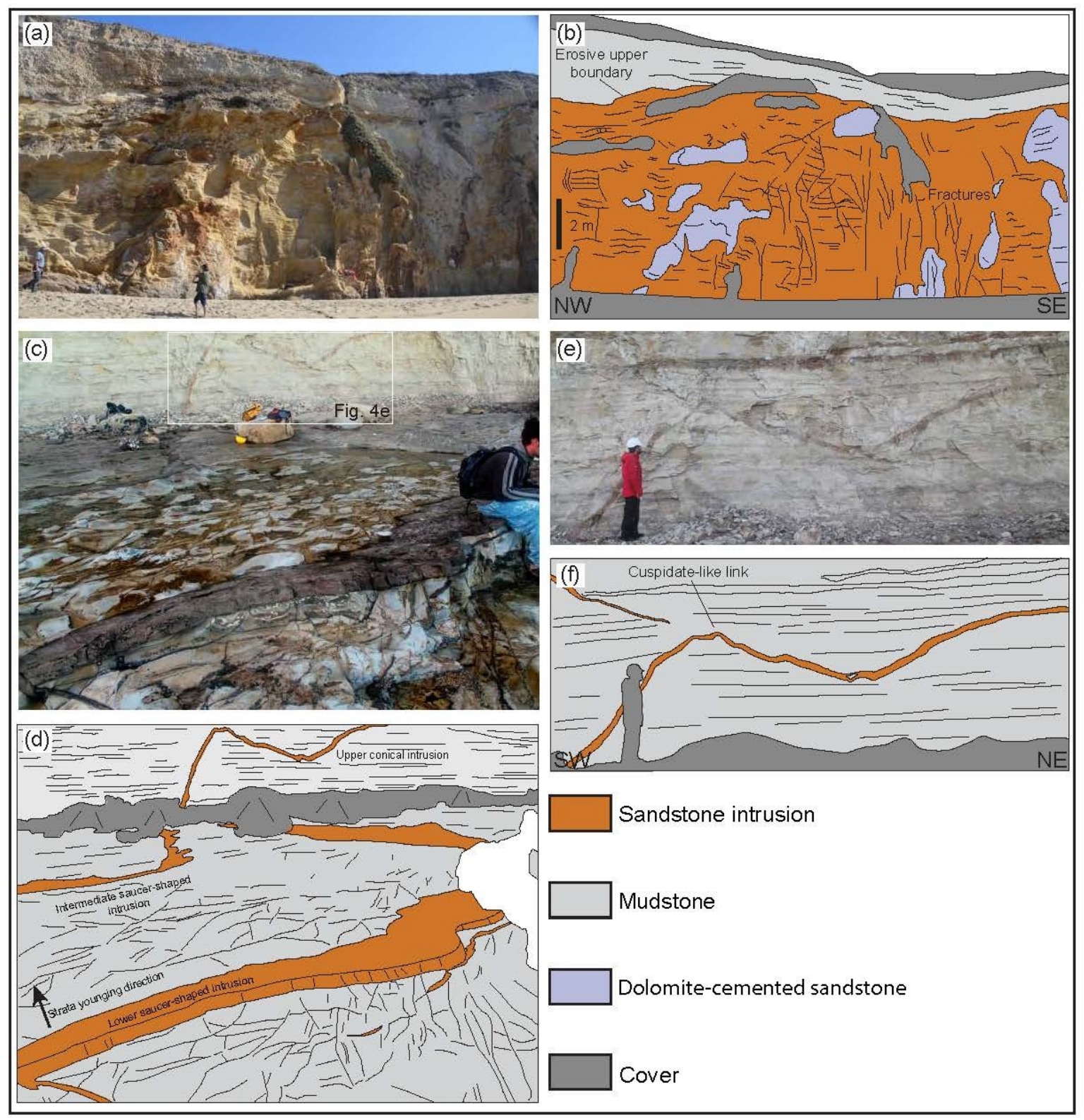

Fig. 4. Main characteristics of sills and saucer-shaped intrusions forming the SCIC. a)

Photograph and interpretative line drawing (b) of a sill cropping out at Panther Beach characterized by a marked upper erosional boundary. Internal structures are clearly visible and

926 fractures cross-cutting the sandstone body. c) Photograph and interpretative line drawing (d)

927 of nested tar-saturated saucer-shaped intrusions recognised at different stratigraphic levels in 928 the Santa Cruz mudstone at 4 Mile Beach. e) Photograph and interpretative line drawing (f) 929 of cross-section of a conical sandstone intrusion cropping out at 4 Mile Beach. Note that this 
This is a non-peer reviewed pre-print.

The Manuscript is currently under review in Marine and Petroleum Geology. Please note the subsequent version of this manuscript may have a different content.
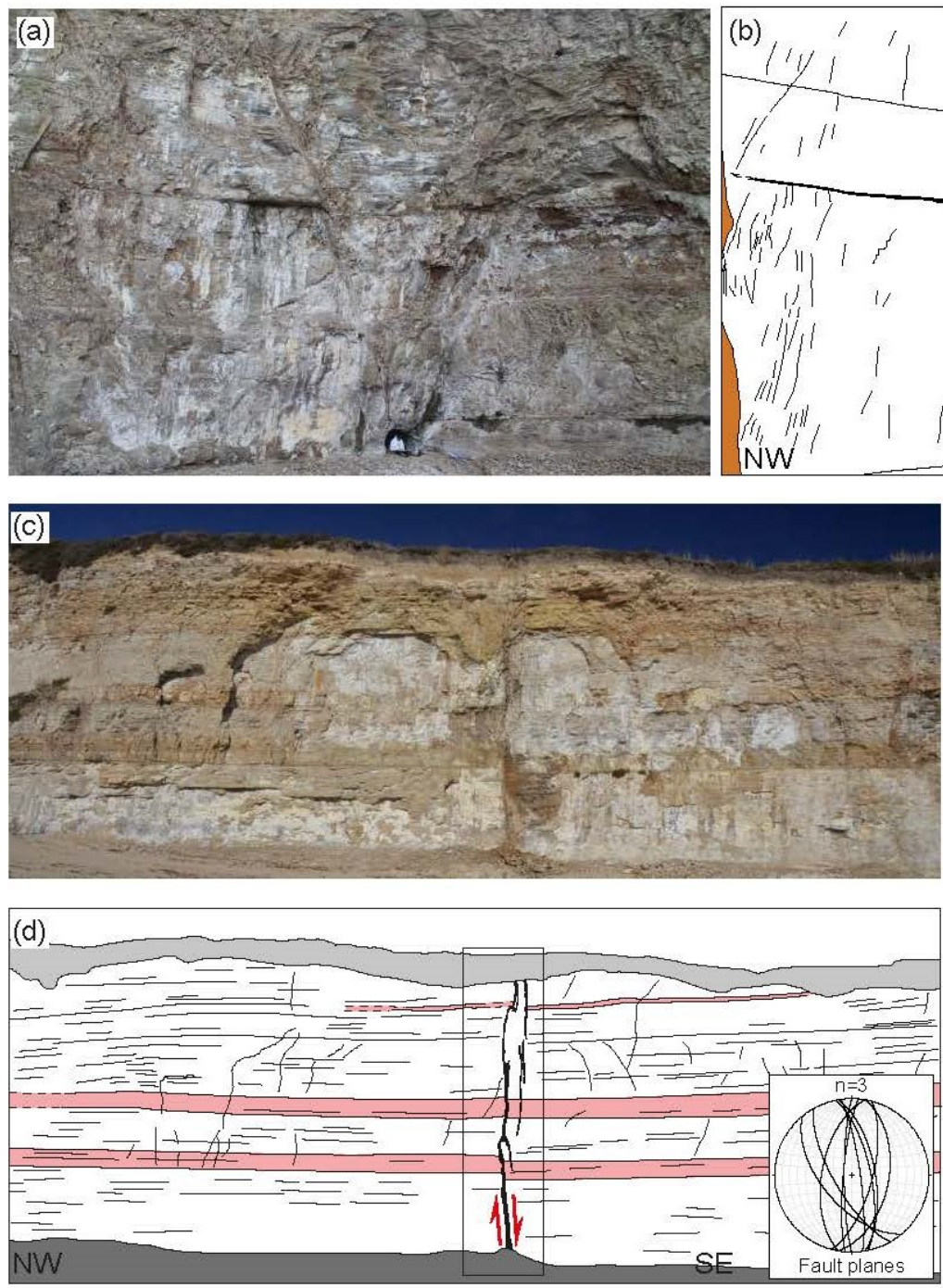
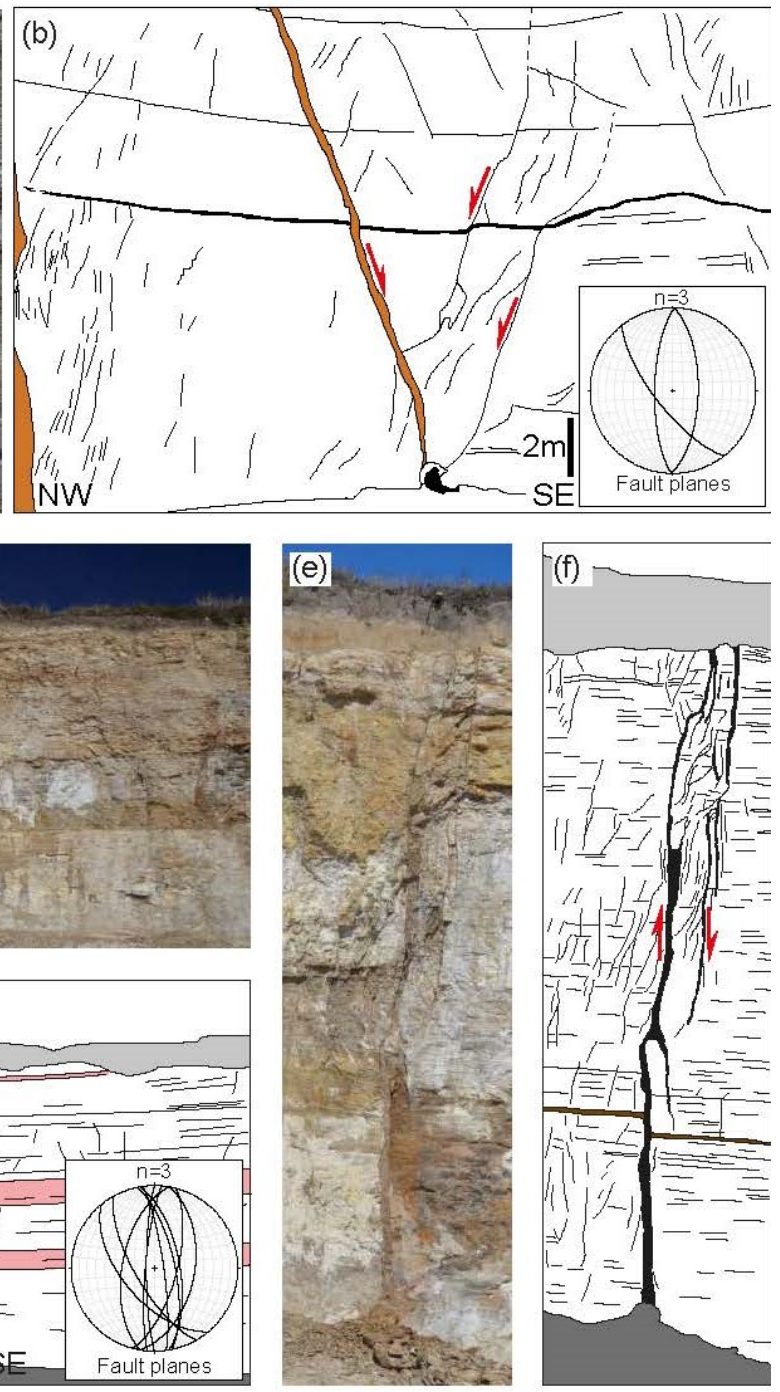

Fig. 5. Main characteristics of sandstone-filled faults forming the SCIC. a) Photograph and interpretative line drawing (b) of a conjugate set of N-S and NNW-SSE faults recognised at Bonny Doon. The amount of offset, up to $15 \mathrm{~cm}$, is provided by a dark marker clay level. c) Photograph and interpretative line drawing (d) of sandstone-filled normal fault recognised at Laguna Creek Beach. e) Photograph and interpretative line drawing (f) of detail from the previous outcrop. Note the complex structure of the fault plane and the sandstone intruded within even the thinnest fault segments. 
The Manuscript is currently under review in Marine and Petroleum Geology. Please note the subsequent version of this manuscript may have a different content.
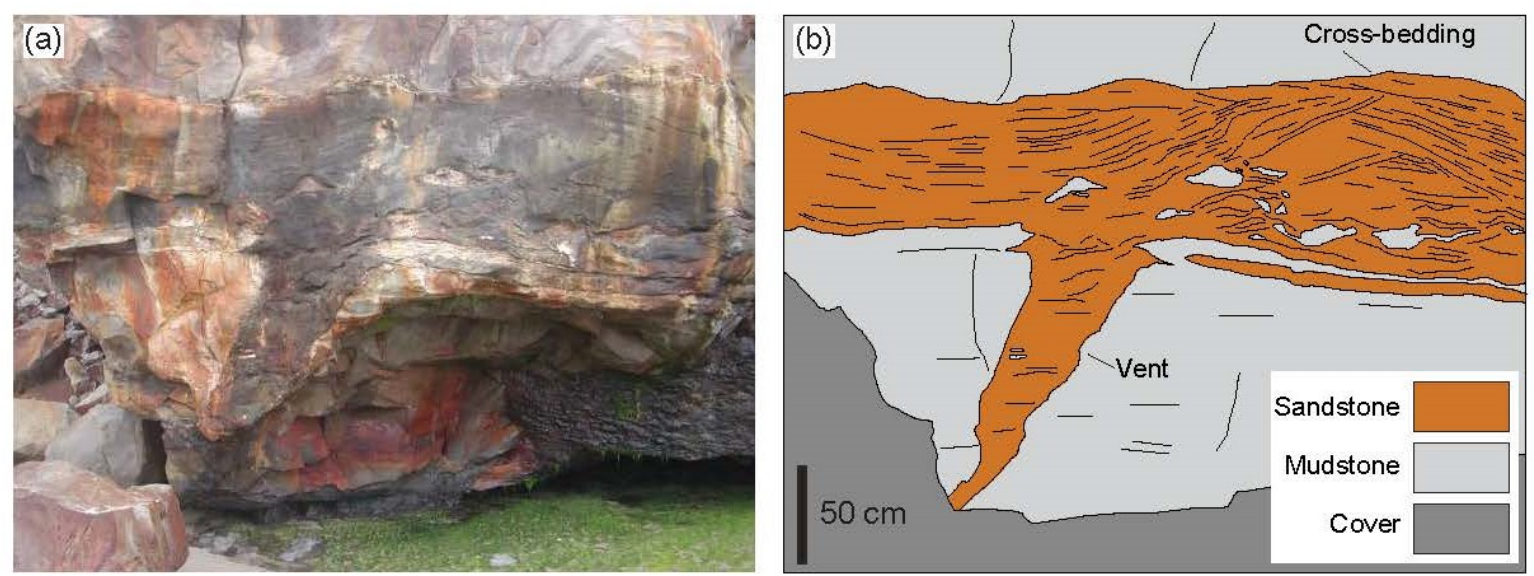

Fig. 6. Main characteristics of extrudites forming the SCIC at Red, White and Blue Beach. a)

Photograph and interpretative line drawing (b) of bed-parallel, mound-shaped extrudite

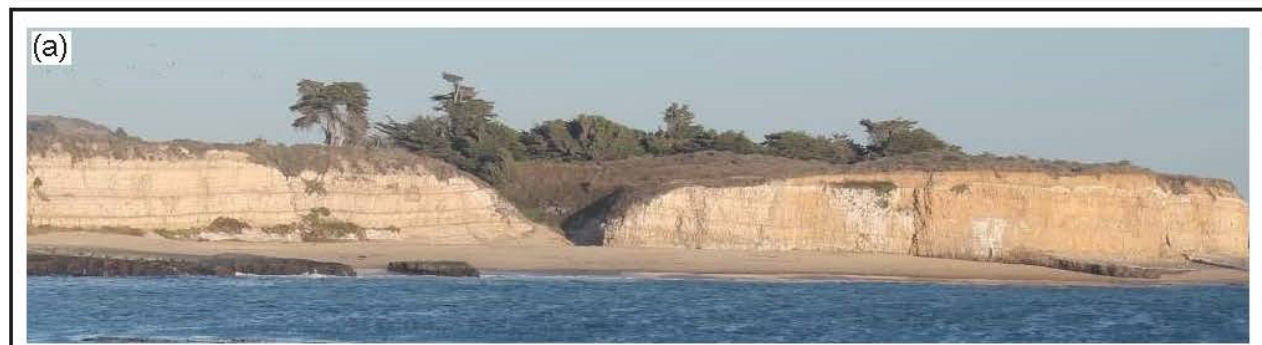

(b)

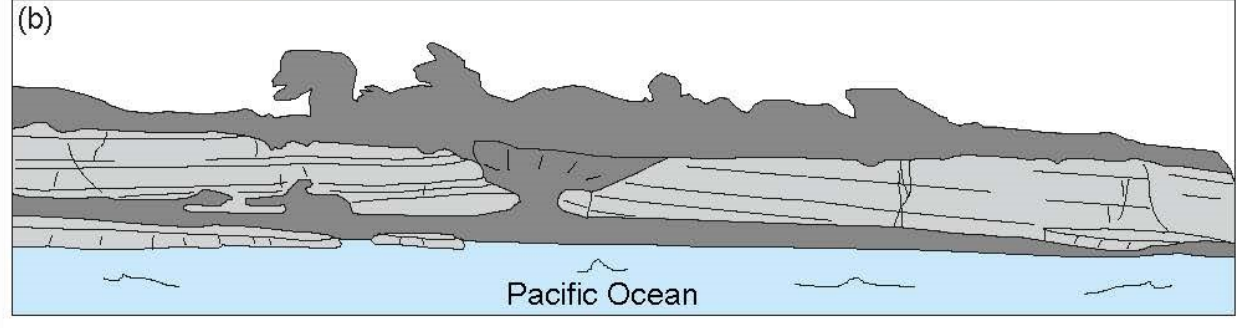

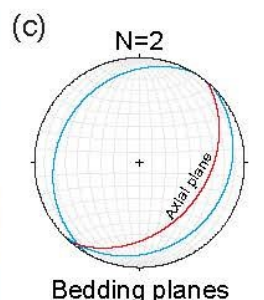

Bedding planes

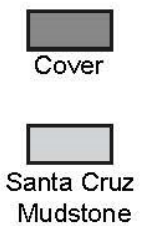

Fig. 7. a) Photograph and interpretative line drawing (b) of NW-SE trending open fold

closely corresponds with the fold hinge zone where outer arc extension fracturing took place. 
This is a non-peer reviewed pre-print.

The Manuscript is currently under review in Marine and Petroleum Geology. Please note the subsequent version of this manuscript may have a different content.
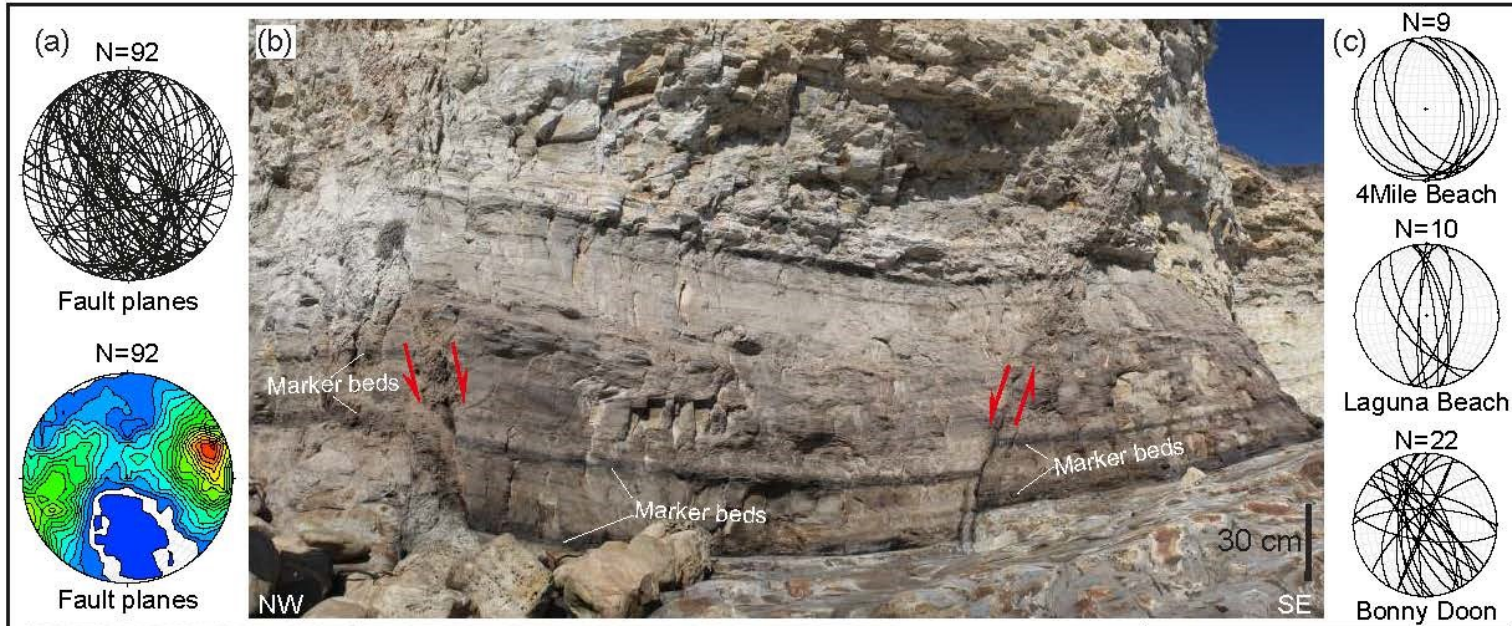

Laguna Beach

$\mathrm{N}=22$
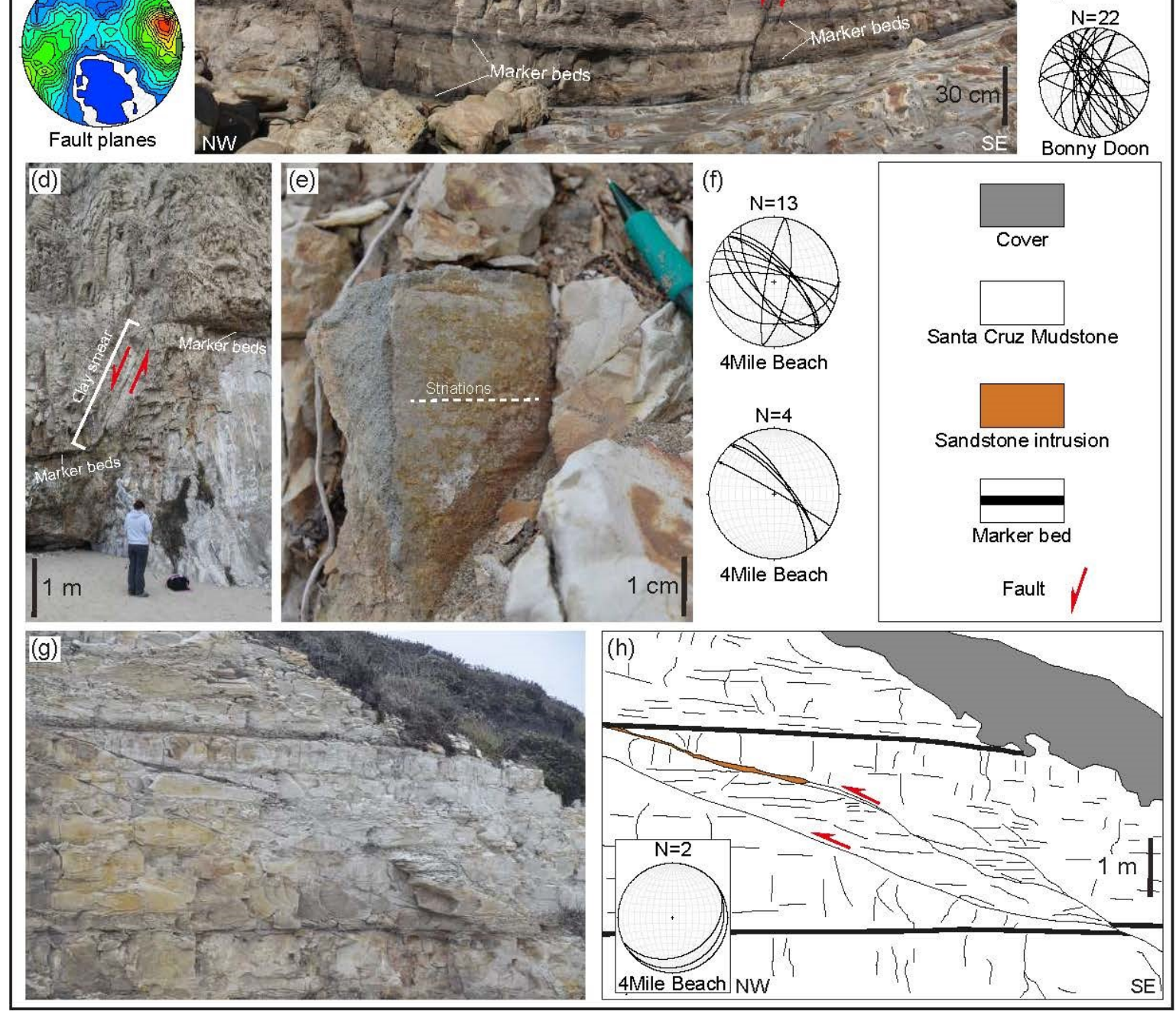

Fig. 8. a) Preferential orientations of faults recognised along the Santa Cruz coastal area. Note that faults shown on stereoplots are dominantly NNW-SSE and N-S trending. b) Conjugate normal faults forming a NNW-SSE trending graben in 4 Mile Beach. The measured amount of the offset, about $20 \mathrm{~cm}$, is based on the displacement of dark maker beds alternating to the 
This is a non-peer reviewed pre-print.

The Manuscript is currently under review in Marine and Petroleum Geology. Please note the subsequent version of this manuscript may have a different content.

961 Santa Cruz Mudstone. c) Lower hemisphere equal area stereographic projections showing the 962 orientation of the normal fault planes (great circles) in some key outcrops recognised along 963 the investigated area. d) Normal fault showing smeared clay along the fault surface at Bonny 964 Doon Beach. e) Striated strike slip fault exploiting a pre-existent discontinuity represented by 965 the boundary between a sandstone intrusion and the Santa Cruz Mudstone at 4 Mile Beach. f) 966 Lower hemisphere equal area stereographic projections showing the orientation of strike-slip 967 faults (great circles) in some key outcrops recognised along the investigated area. g) Reverse 968 faults recognised at 4 Mile Beach. Note the occurrence of tar-saturated injected sandstone 969 within dilational jogs occurring along the fault plane. h) Line drawing interpretation. 
This is a non-peer reviewed pre-print.

The Manuscript is currently under review in Marine and Petroleum Geology. Please note the subsequent version of this manuscript may have a different content.
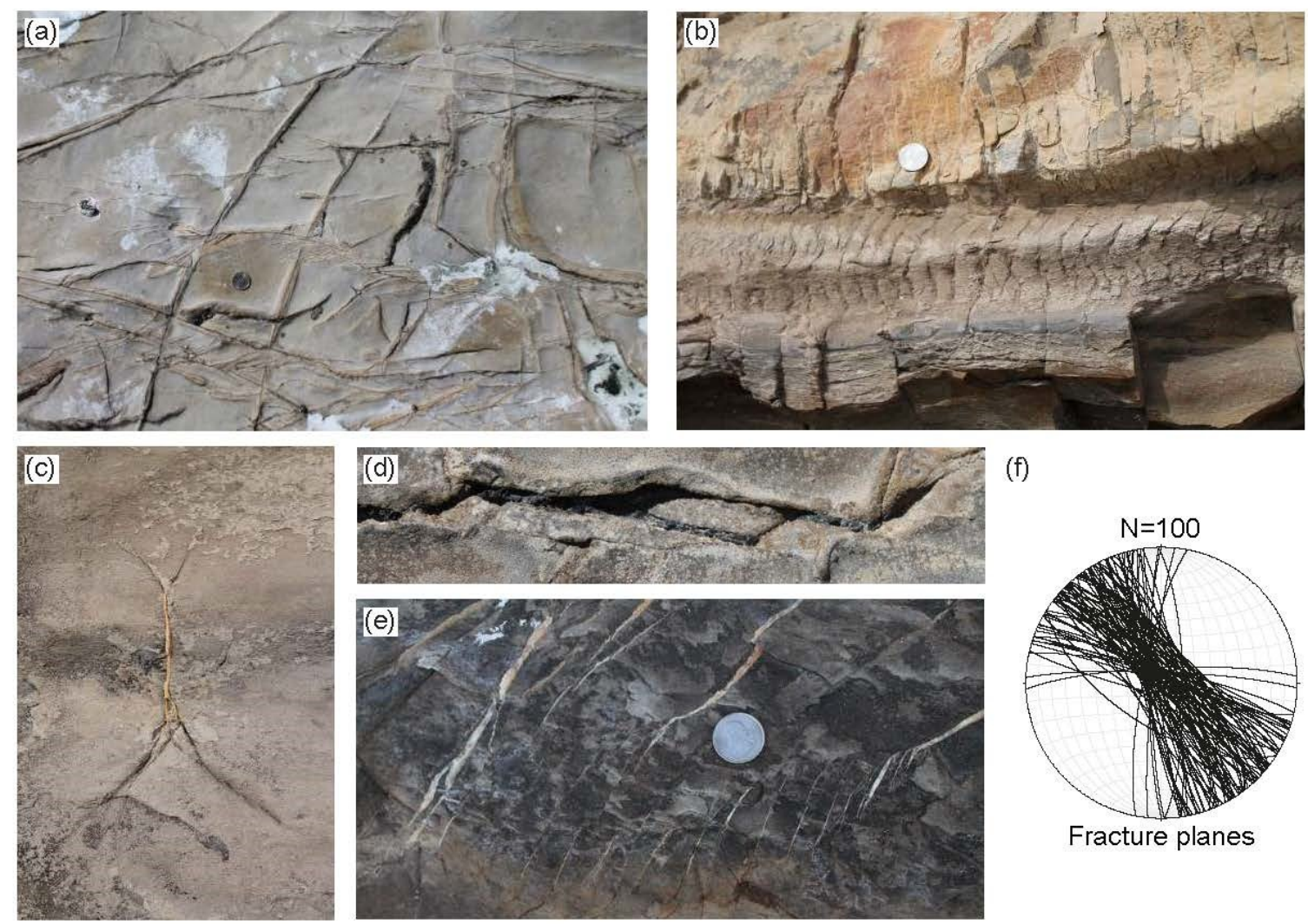

(f)
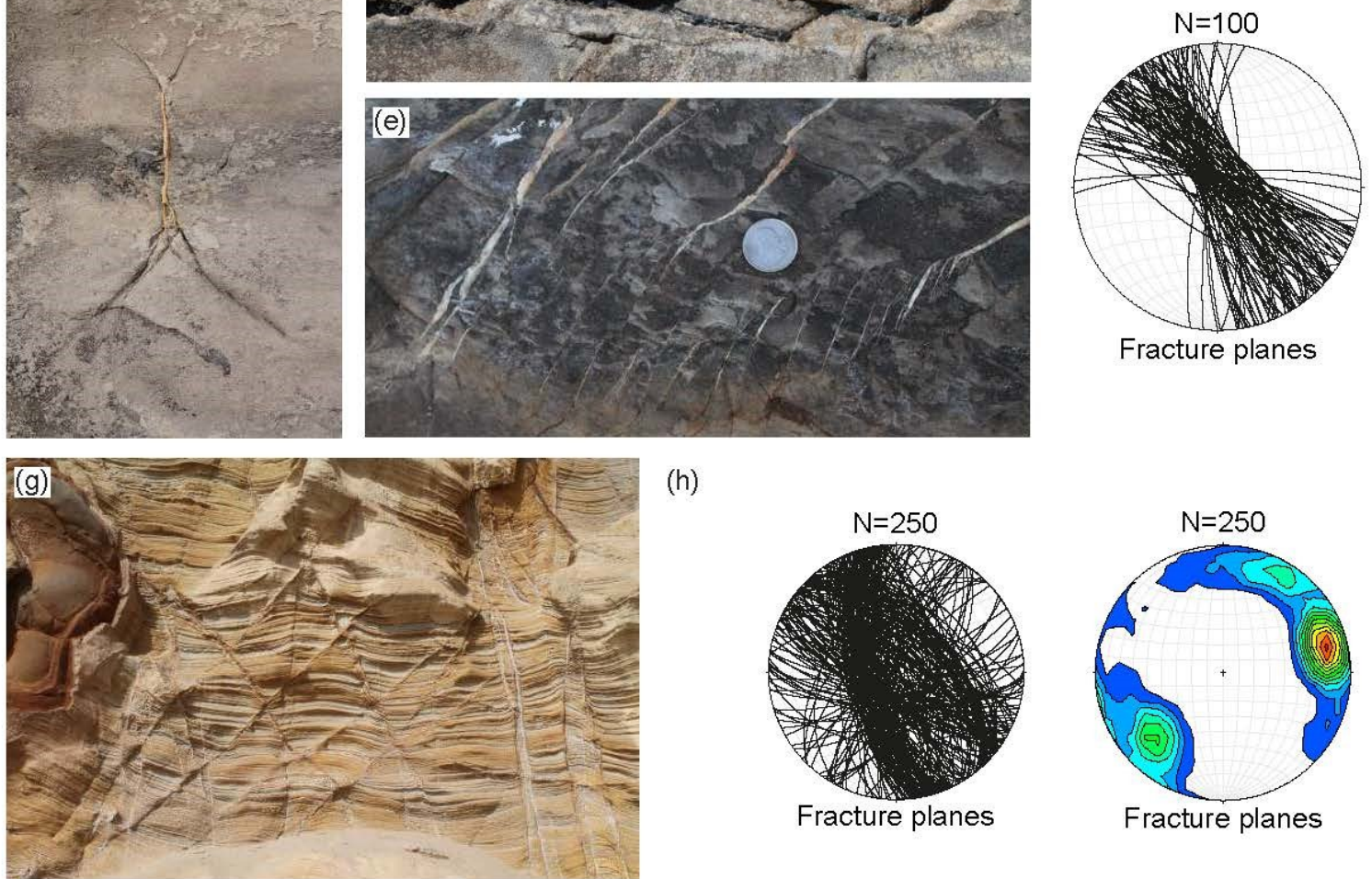

(h)
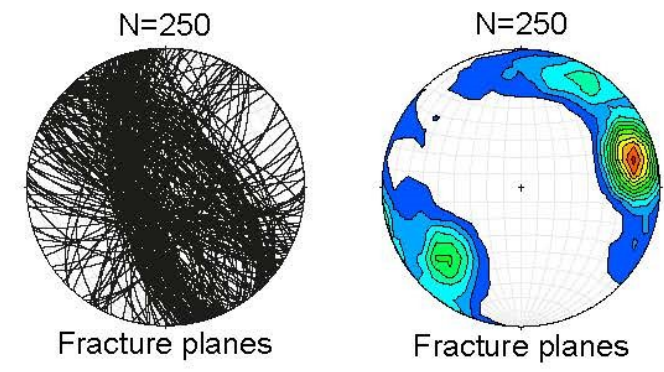
at 4 Mile Beach. e) Calcite-filled, en-echelon fractures at 4 Mile Beach. f) Lower hemisphere equal area stereographic projections showing the orientation of fractures (great circles) at 4 Mile Beach. g) Sets of conjugate fractures cutting through sandstone intrusions at Panther

Fig. 9. a) Details of the fracture network affecting the Santa Cruz Mudstone observable in plan view at 4 Mile Beach. b) S-shaped fractures and c) fracture meshes recognised at 4 Mile Beach. Note the occurrence of calcite within the fractures. d) Tar-saturated fracture recognised Beach. Note the resulting honeycomb structure. h) Lower hemisphere equal area stereographic projections showing the orientation of fractures (great circles) at Panther Beach. 
This is a non-peer reviewed pre-print.

The Manuscript is currently under review in Marine and Petroleum Geology. Please note the subsequent version of this manuscript may have a different content.

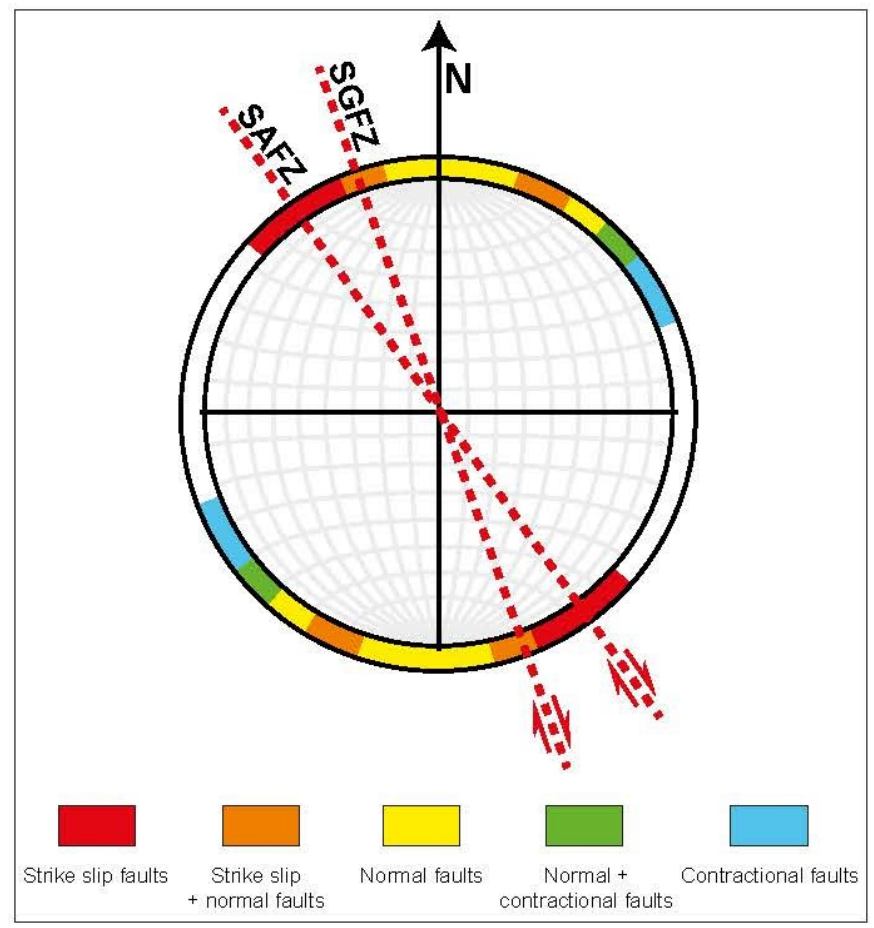

982 Fig. 10. Diagram showing the main range of trends of the tectonic structures recognised in the

983 Santa Cruz Coastal area. The trends of the San Andres and San Gregorio fault zones are also 984 included (red dotted lines).
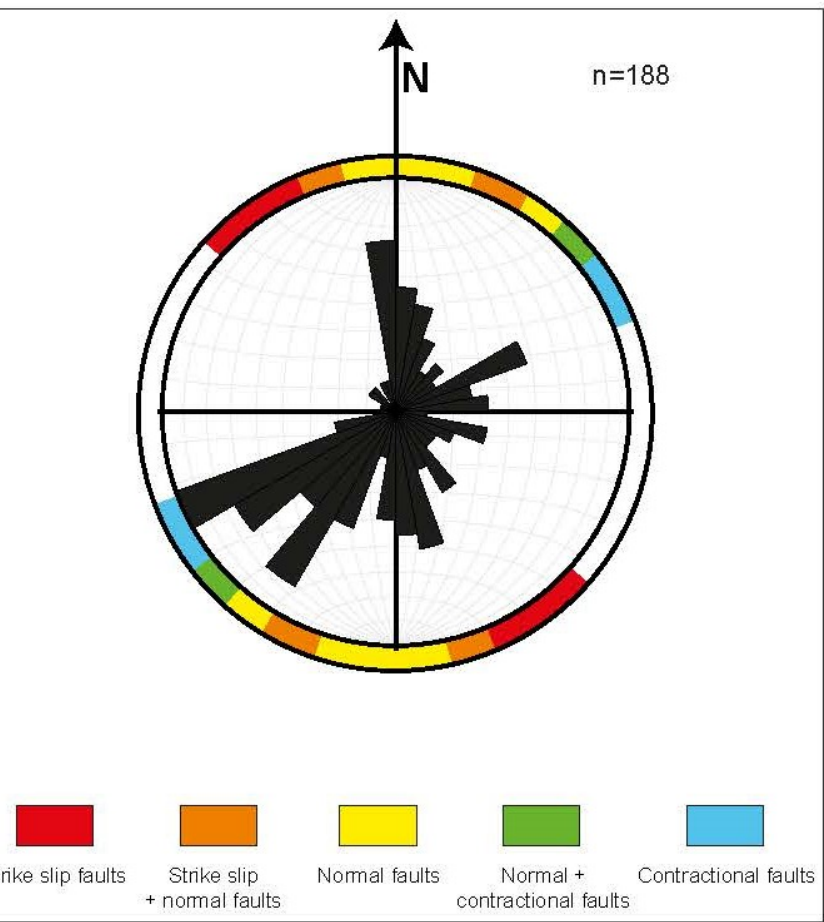
This is a non-peer reviewed pre-print.

The Manuscript is currently under review in Marine and Petroleum Geology. Please note the subsequent version of this manuscript may have a different content.

987 Fig. 11. Diagram showing the main relationships between dike orientations and fault and

988 fracture patterns. Note that most dikes have been emplaced along extensional structures.
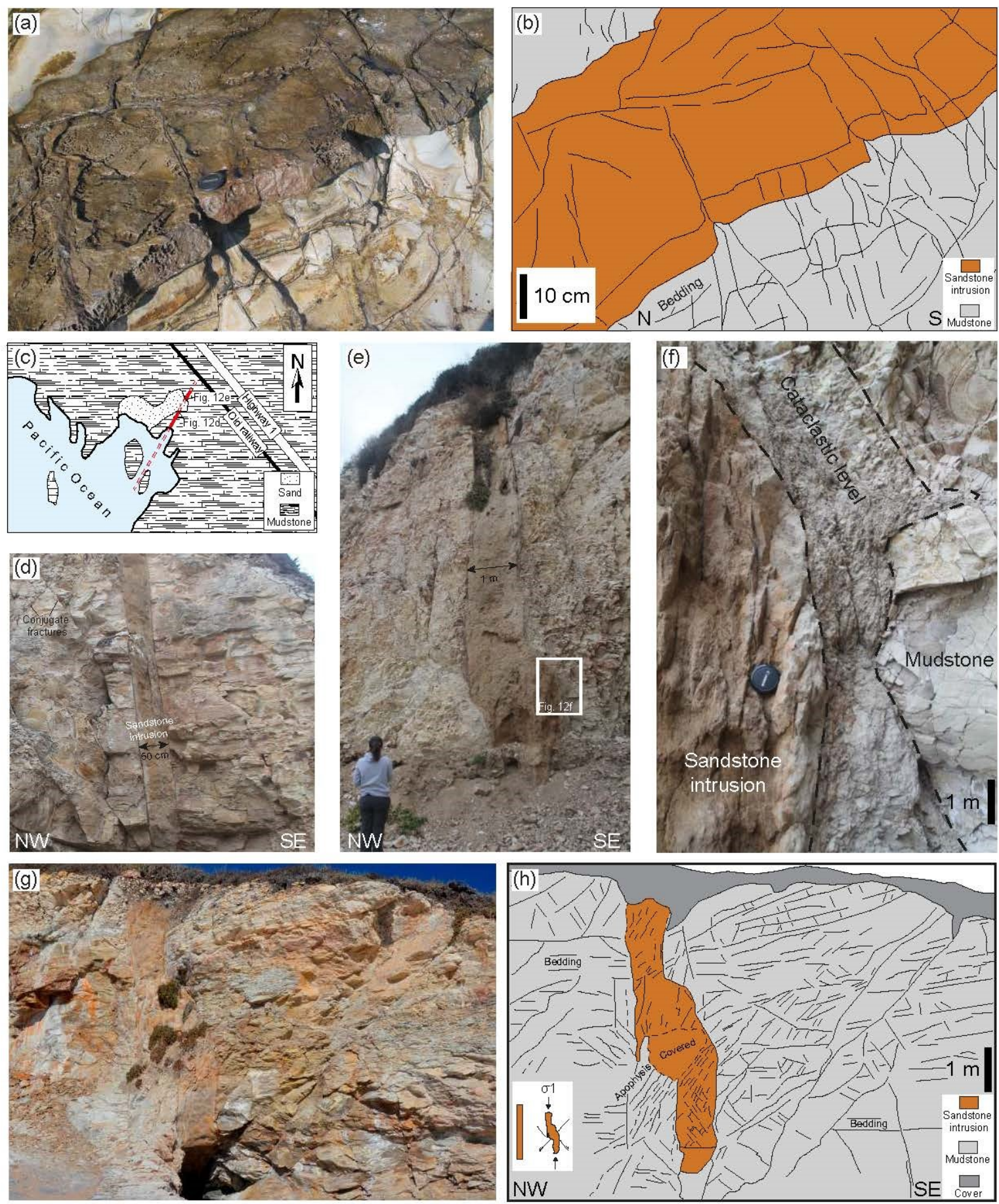

Fig. 12. Evidence for tectonic overprint of sandstone intrusions along the Santa Cruz coastal area. a) Photograph and interpretative line drawing (b) of $10 \mathrm{~cm}$-thick sills overprinted by 
This is a non-peer reviewed pre-print.

The Manuscript is currently under review in Marine and Petroleum Geology. Please note the subsequent version of this manuscript may have a different content.

993 fractures recognised at 4 Mile Beach. Observable mechanical discontinuities mainly consist 994 of fractures nearly orthogonal to the sill-host mudstone interface and bedding surfaces. Sill995 parallel fractures are notably lacking. c) Sketch map of Shark Fin Cove with the sandstone 996 intrusion shown in red. d) Portion of the considered sandstone intrusion scarcely affected by 997 later tectonic deformation. Conjugate fractures are visible in the host strata but, importantly, 998 do not affect the dike-host-strata interface. e) Same dike in a sector characterized by strong 999 post-emplacement deformation probably related to a normal fault zone. The deformed dike 1000 shows steps and thickened sections due to vertical compression. Most of the deformation is 1001 focussed along the dike-host-strata interface where a thick unit of cataclastic material forms. 1002 f) Photograph and interpretative line drawing (g) of a dike affected by post emplacement 1003 deformation recognised at Laguna Creek Beach. Similar to the previous example, vertical 1004 compression is accommodated by conjugate fractures, stepped geometry and thickening in the 1005 central portion of the dike. 
This is a non-peer reviewed pre-print.

The Manuscript is currently under review in Marine and Petroleum Geology. Please note the subsequent version of this manuscript may have a different content.
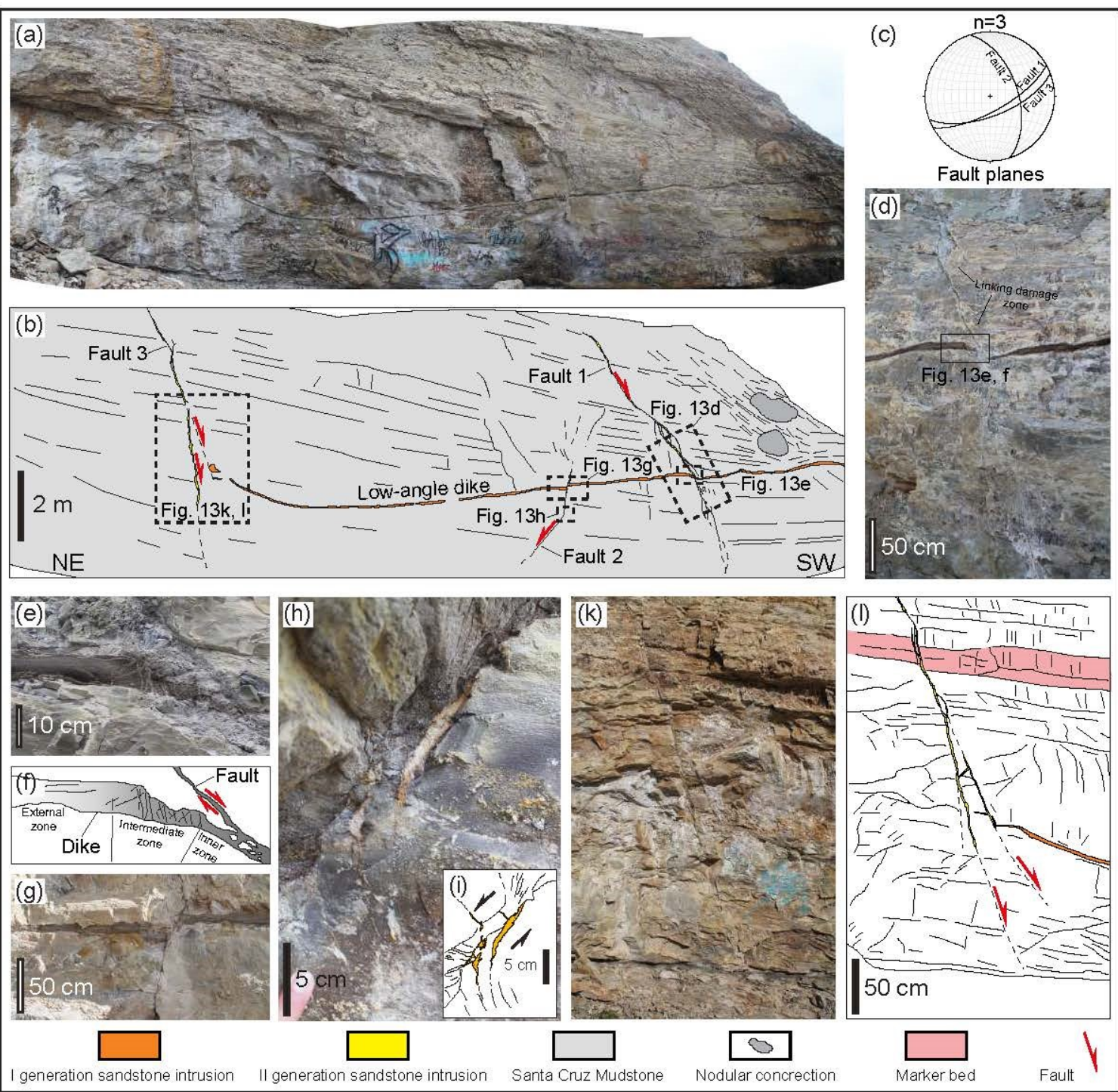

Fig. 13. a) Photograph and interpretative line drawing (b) of cross-cutting relationships

1009 between the two recognised generations of sandstone intrusions at Panther Beach. c) Lower

1010 hemisphere equal area stereographic projections (great circles) showing the orientation of the

1011 conjugate sandstone-filled normal faults recognised at Panther Beach. d) Fault 1 shows a cm1012 scale offset and is only partially filled by sand. e) Close-up of Fault 1 showing the younger 1013 generation of sandstone intrusions emplaced along the fault plane, and the low-angle dike 1014 belonging to the older generation that is fractured and thinned in the proximity of the fault 1015 plane. Line drawing interpretation showing fracture distribution along the low-angle dike with respect to the distance from the fault plane. f) Photograph of Fault 2. g) En echelon dilation 
This is a non-peer reviewed pre-print.

The Manuscript is currently under review in Marine and Petroleum Geology. Please note the subsequent version of this manuscript may have a different content.

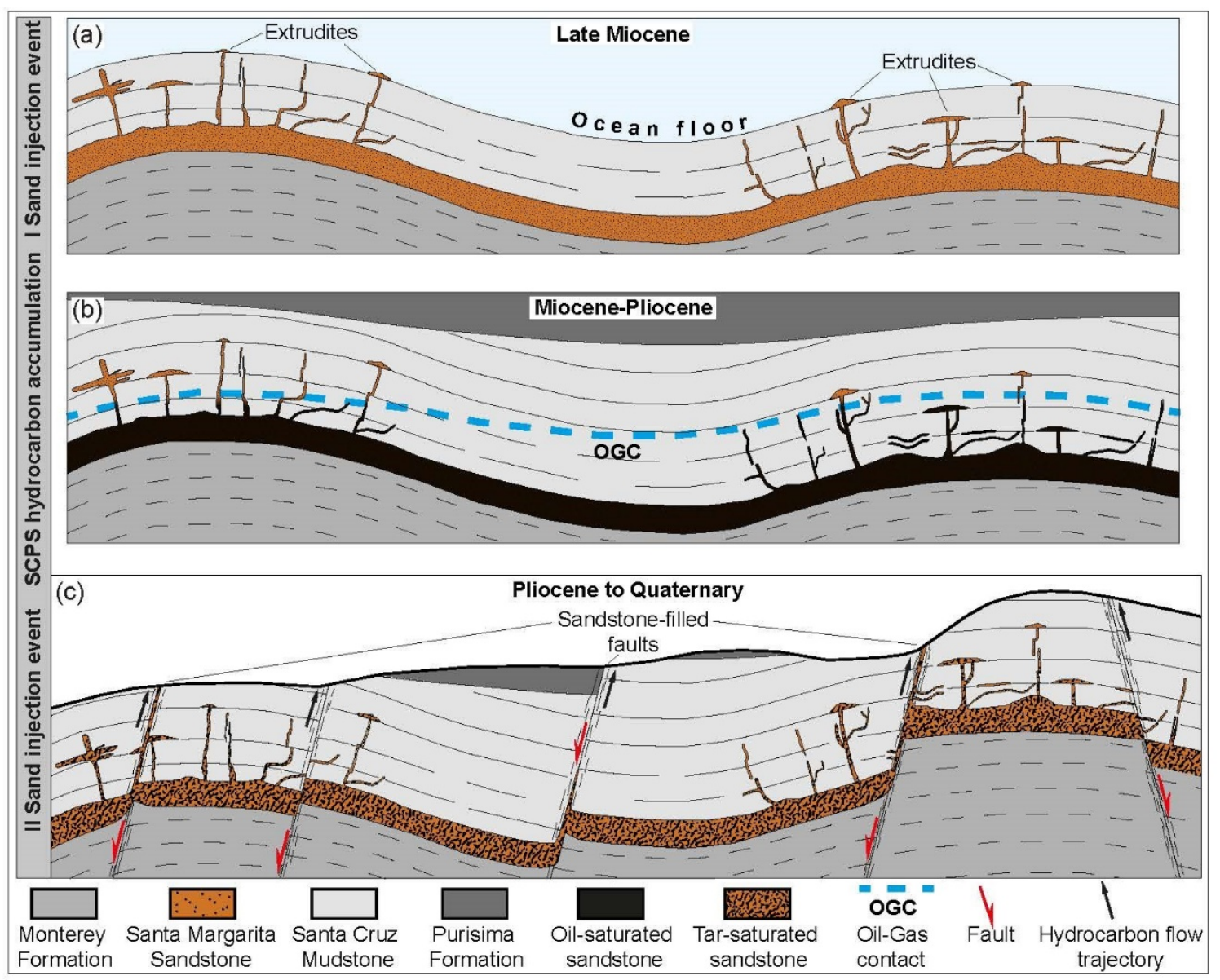

Fig. 14. Evolutionary model proposed to explain the occurrence of the Santa Cruz Injection Complex and the Santa Cruz petroleum system. a) The Santa Cruz Injection Complex emplacement mainly occurred during the Late Miocene following a contractional deformation stage affecting the Santa Cruz sedimentary succession. Sand remobilization and emplacement related to the first sand injection event was particularly intense in the correspondence of the anticlines where fluid overpressure generated by the squeezing of the Santa margarita Sandstone and fracturing promoted by outer arc extension created suitable conditions. The age of the sandstone intrusion event is constrained to the Late Miocene by the extrudites recognised in the study area. b) The unconsolidated state of the Santa Cruz Mudstone and the 
This is a non-peer reviewed pre-print.

The Manuscript is currently under review in Marine and Petroleum Geology. Please note the subsequent version of this manuscript may have a different content.

1030 successive accumulation of sediments at the top of the sandstone intrusion complex caused 1031 the resealing of the system and favoured the accumulation of hydrocarbons pertaining to Santa 1032 Cruz petroleum system in the newly-formed sandstone network between the Late Miocene 1033 and the Early Pliocene. c) Uplift and faulting related to the Pliocene-Quaternary strike-slip 1034 tectonic evolution of the area caused the definitive failure of the Santa Cruz petroleum system. Tar-saturated sandstones are what remain of this petroleum system. 